Shaon Lahiri

Rosaine N Yegbemey

Neeta Goel

Leja Mathew

Jyotsna Puri

\section{Promoting latrine use in India}

August 2017
Scoping

Paper 8
Sanitation

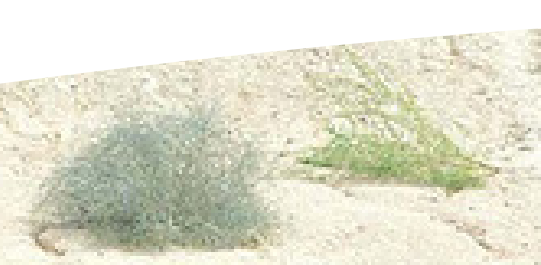

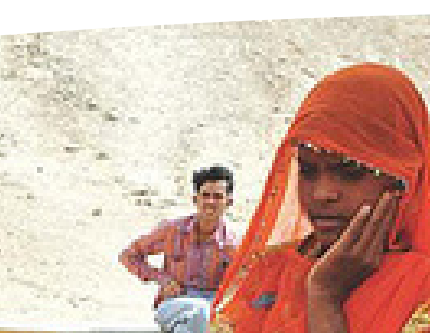
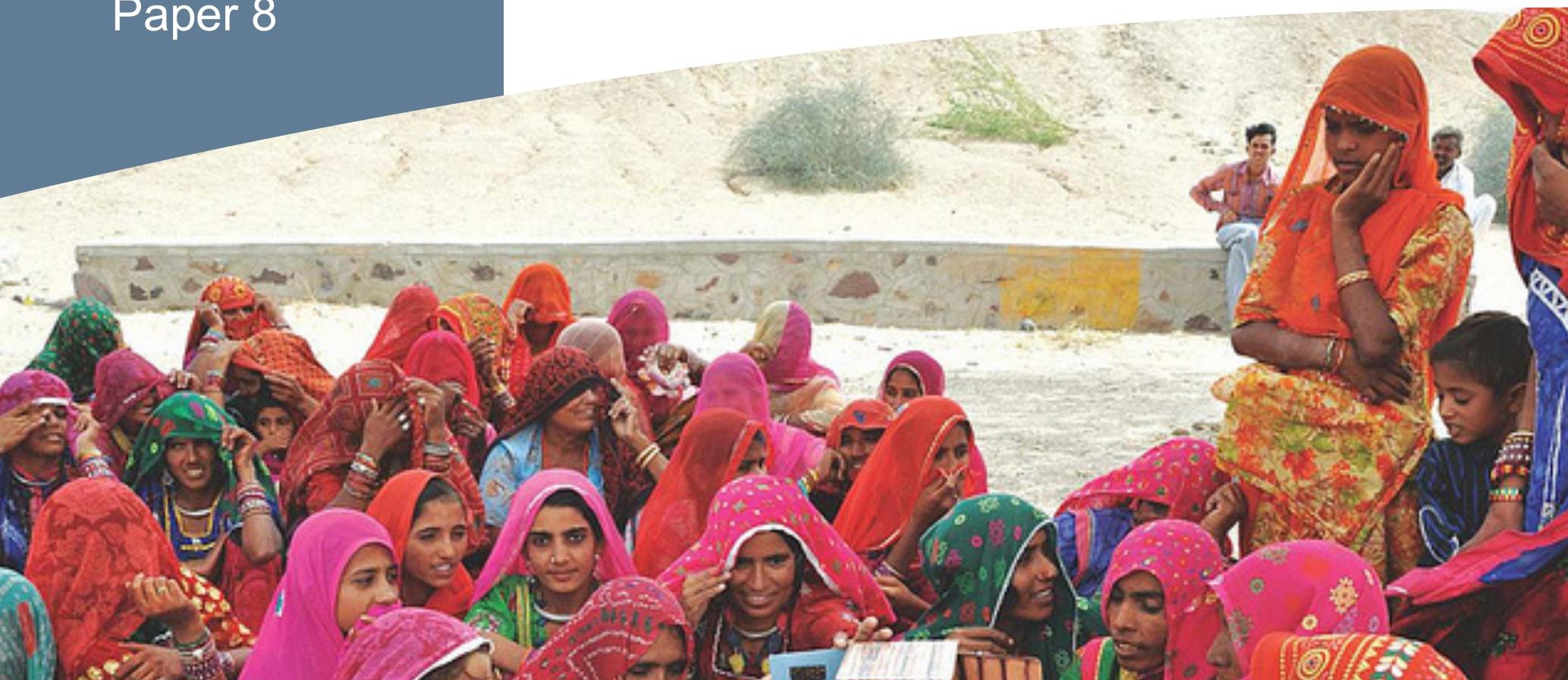

20

Nons.
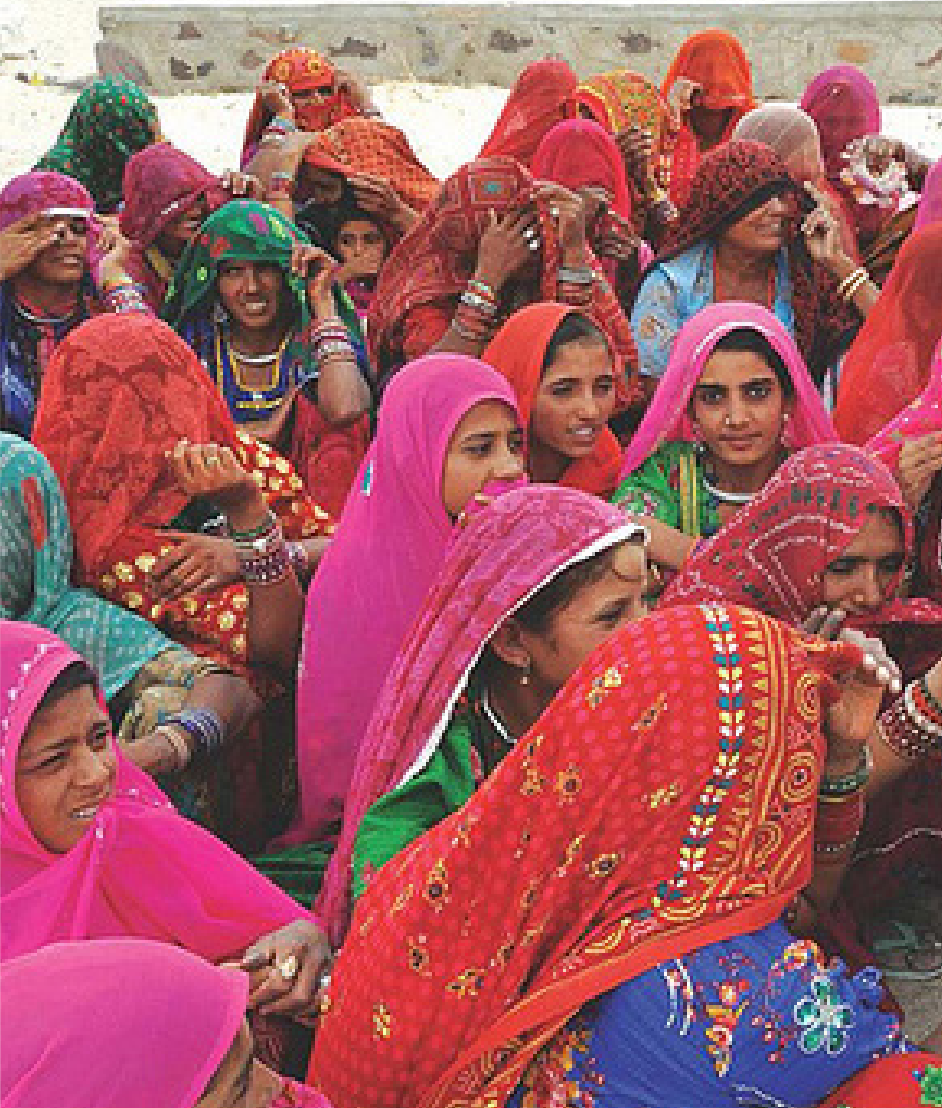

(1) 3$)^{-6}$
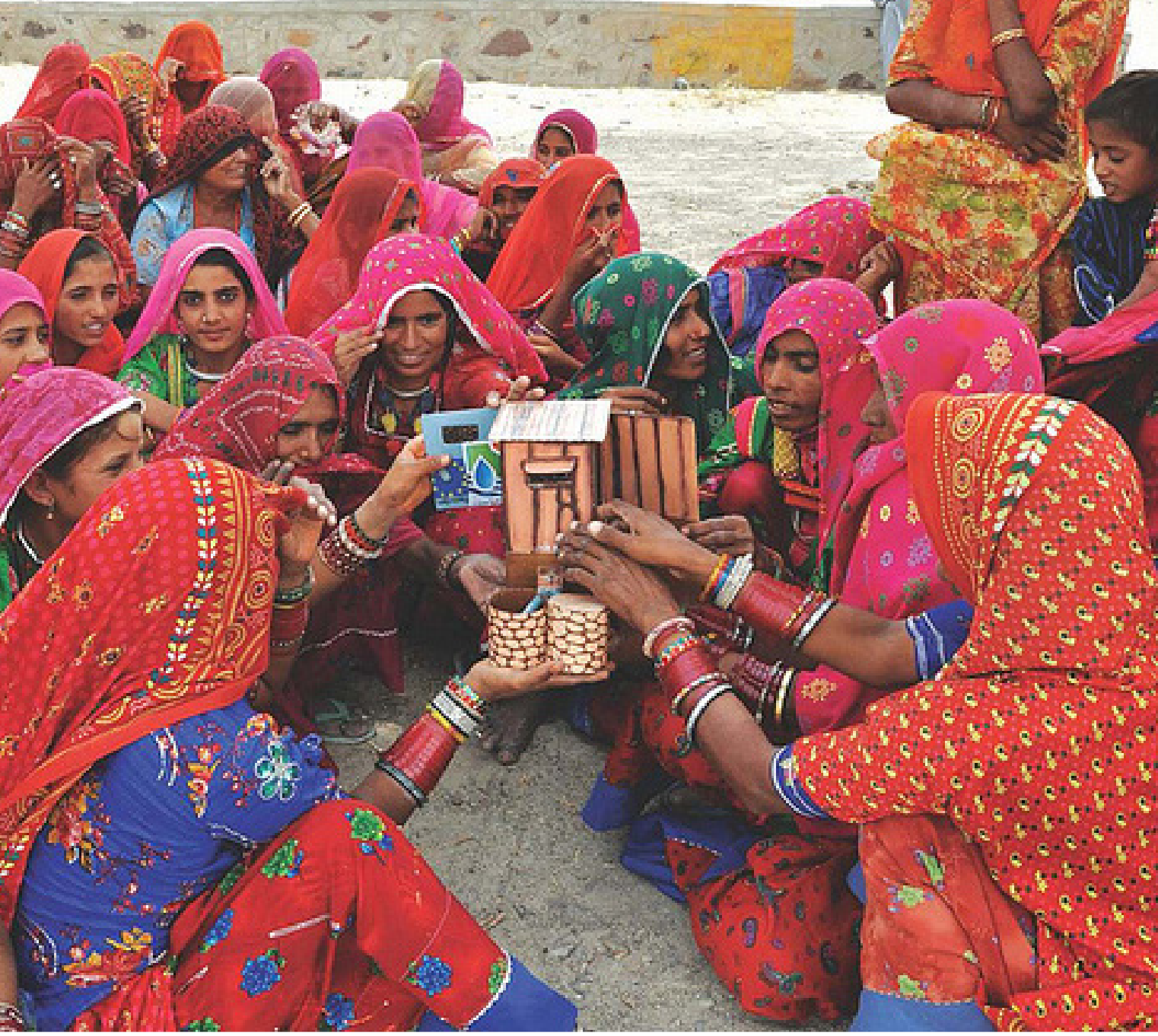


\section{About 3ie}

The International Initiative for Impact Evaluation (3ie) is an international grant-making NGO promoting evidence-informed development policies and programmes. We are the global leader in producing and synthesising high-quality evidence of what works, for whom, how, why and at what cost. We believe that better and policy-relevant evidence will help make development more effective and improve people's lives.

\section{3ie scoping papers}

3ie thematic window grant programmes typically start with a consultative process that includes a scoping study that identifies the current state of impact evaluation evidence in a particular sector. Scoping studies lay out the landscape of what is known and help identify priority policy questions. Although thematic windows are conducted in response to donor demand, this consultation process gives developing country stakeholders a voice in setting key priorities and identifying research questions.

\section{About this scoping paper}

This scoping paper provides a systematic overview of the quantitative evidence on latrine use in rural India. It is part of background scoping research conducted to assess the evidence base on interventions to increase latrine use in rural India, with particular attention to causal or correlational studies. This paper is part of the Promoting Latrine Use in Rural India thematic grant window. All author affiliations are at the time of report completion, except where otherwise noted.

All content is the sole responsibility of the authors and does not represent the opinions of 3ie, its donors or its Board of Commissioners. Any errors and omissions are also the sole responsibility of the authors. Please direct any comments or queries to the corresponding author, Shaon Lahiri, at slahiri@3ieimpact.org.

Funding for the grant window has been provided to 3ie by the Bill \& Melinda Gates Foundation.

Suggested citation: Lahiri, S, Yegbemey, RN, Goel, N, Mathew, L and Puri, J, 2017. Promoting latrine use in rural India. 3ie Scoping Paper 8. New Delhi: International Initiative for Impact Evaluation (3ie)

3ie Scoping Paper Series executive editors: Beryl Leach and Emmanuel Jimenez Production manager: Angel Karya

Assistant production manager: Akarsh Gupta

Copy editor: Jaime L Jarvis

Proofreader: Yvette Carboneau

Cover design: John F McGill and Akarsh Gupta

Cover photo: European Union

(c) International Initiative for Impact Evaluation (3ie), 2017 
Promoting latrine use in rural India

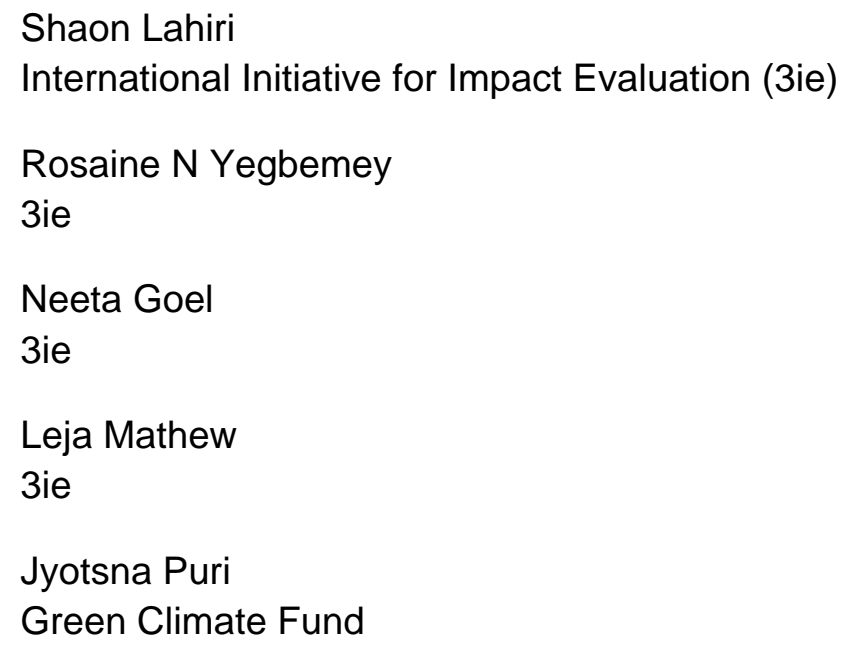

3ie Scoping Paper 8

August 2017

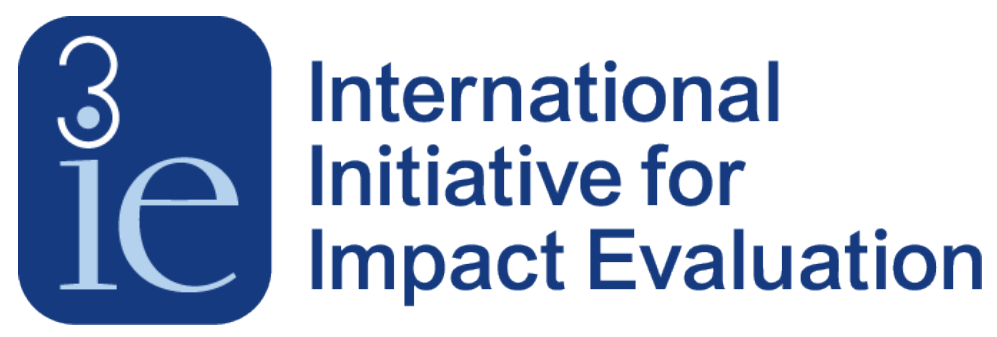




\section{Acknowledgements}

This paper has been prepared by 3ie as part of the Promoting Latrine Use in Rural India Thematic Window. We thank Radu Ban for his constant and consistent support of 3ie's promoting latrine use evidence grant programme and substantive inputs to our efforts.

3ie staff prepared the paper under the direction of Jyotsna Puri. We are thankful to the internal reviewers, Beryl Leach and Hugh Waddington, and to anonymous external reviewers for their comments, which helped improve this paper. We are grateful to Ritwik Sarkar, Priyanka Dubey and Avantika Bagai for their administrative support in organising the workshops and field visit. Our thanks also go to John Eyers for conducting the systematic search of the literature and providing helpful guidance on search strategies. We are grateful to Radhika Menon for her continuing support and guidance.

We thank our thought-partners at the research institute for compassionate economics for their partnership on this thematic window.

We thank all those who participated in our two consultative workshops in April and July 2016. Feedback from both these events have informed our understanding of rural Indian sanitation. 


\section{Summary}

Open defecation represents a major social and health burden for individuals, families and societies. India alone accounts for approximately 60 per cent of the global population defecating in the open, with the majority residing in rural India. Open defecation spreads diseases such as diarrhoea, schistosomiasis and trachoma and results in stunting and malnutrition of children. It can be dangerous and represent an affront to the dignity of vulnerable groups such as women, adolescent girls, the elderly and individuals with disabilities.

This scoping study informs the focus of 3ie's thematic window on Promoting Latrine Use in Rural India. It examines the state of rigorous evidence regarding latrine use in rural India, as well as benefitting from a consultation with experts and a field visit.

We conducted a systematic literature search in March 2016 to answer the research question, 'What is the state of quantitative evidence of latrine use in rural India?' We were interested only in completed quantitative studies that examine latrine use as a primary or secondary outcome. Only 11 studies met inclusion criteria, and of these, four studies used experimental study designs. The marked lack of studies measuring causal change represents a critical knowledge gap and priority area that needs to be addressed by future research.

We find that the most frequently cited barriers to latrine use were knowledge, attitudes and practices related to latrine use and poor quality of latrines. Latrine use is measured in various ways. The most common method is surveys that solicit self-reported latrine use in a household. We also examine correlations between latrine use and different subgroups and explore demand-driven approaches to promoting latrine use. The most common approaches to encourage demand in rural India are community mobilisation, such as Community-Led Total Sanitation. A clear finding from our review is that latrine design and functionality are important determinants of latrine use. Knowledge, attitudes and practices that inhibit latrine use must be addressed through reframing latrines as attractive commodities.

Our findings lead to several recommendations for future research. First, effective sanitation efforts must give adequate weight to the sociohistorical nature of entrenched behaviours that have been reinforced by generations of habit. Shifting these behaviours requires multilevel interventions that target multiple determinants of behaviour. The use of psychosocial theories of behaviour change allows for a framework in which different intervention components can be tested. Second, sanitation efforts must conduct appropriate disaggregated and formative analyses to address the differential needs of and programme impacts on vulnerable populations such as women, children, individuals from lower socioeconomic classes and scheduled castes and tribes. Third, measuring latrine use is difficult, relies primarily on self-reporting and observation and is prone to bias. Future efforts should explore triangulating the measurement of latrine use through disaggregated survey instruments that combine observation and self-reporting. 


\section{Contents}

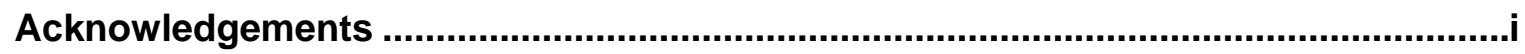

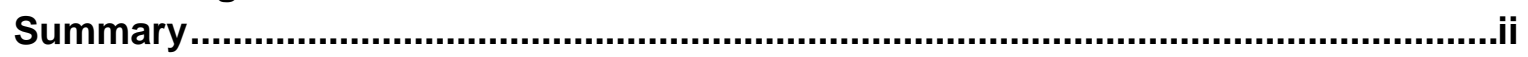

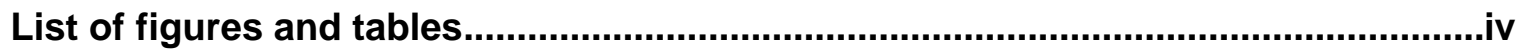

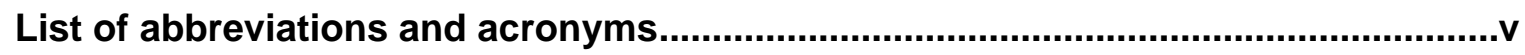

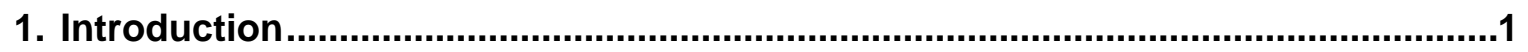

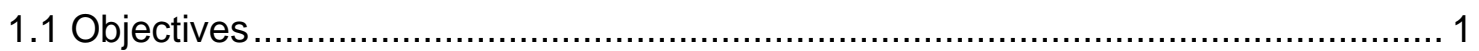

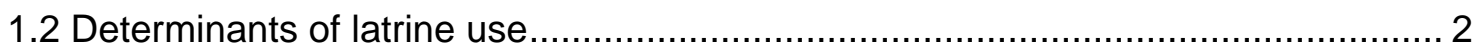

1.3 Demand-driven approaches to ending open defecation ..................................... 2

1.4 The emergence of behavioural science in demand-driven approaches to sanitation

2. Methods

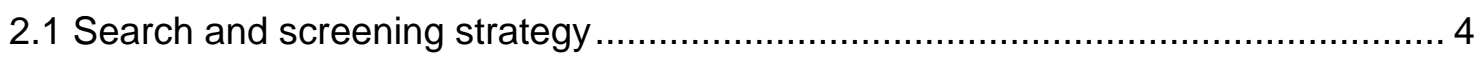

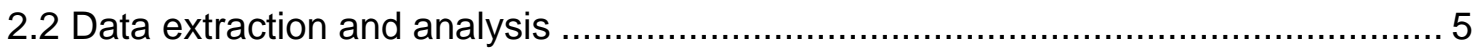

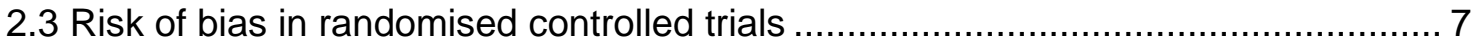

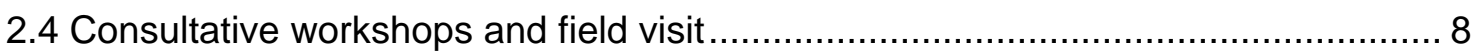

2.5 Limitations

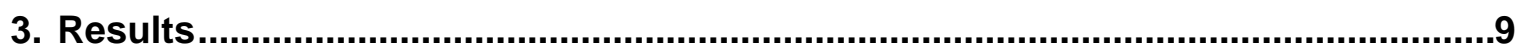

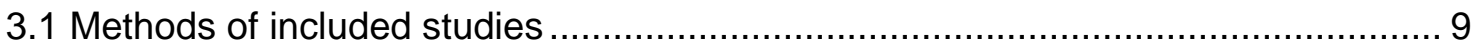

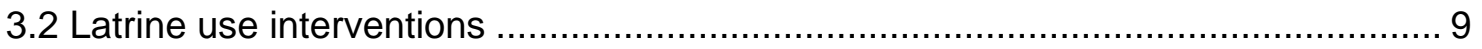

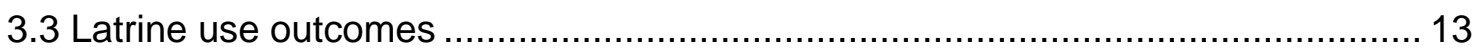

3.4 Impact of interventions on latrine use and coverage .......................................... 14

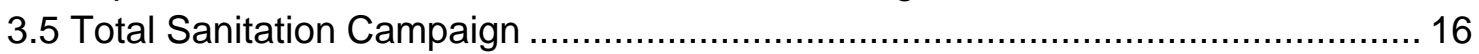

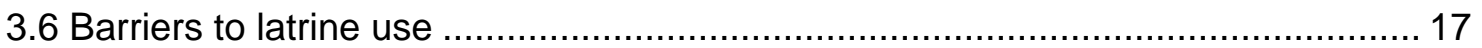

3.7 Risk of bias assessment for randomised controlled trials.................................... 20

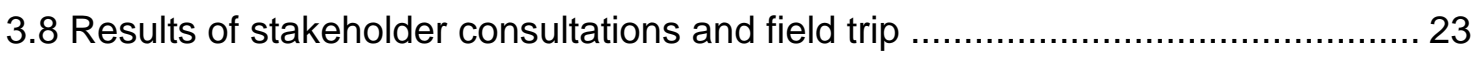

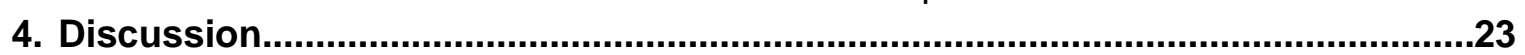

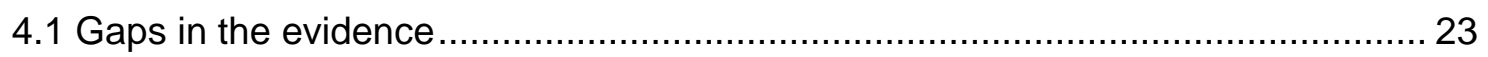

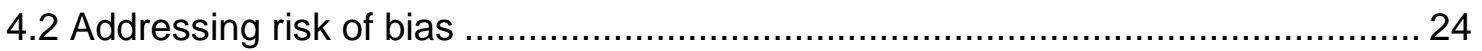

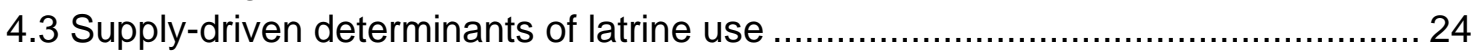

4.4 Demand-driven approaches to latrine use ......................................................... 25

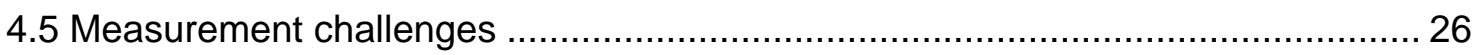

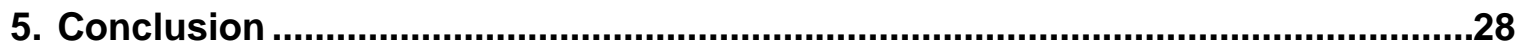

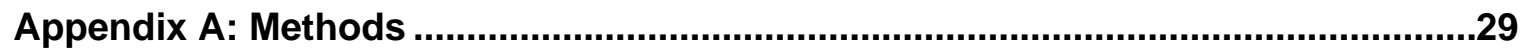

Appendix B: Complete list of variables extracted from included studies ................31

Appendix C: List of included studies...................................................................34

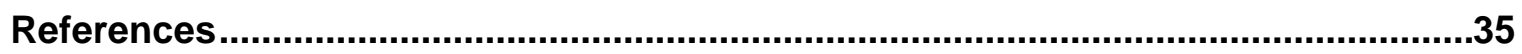




\section{List of figures and tables}

Figure 1: PRISMA diagram of study selection process ............................................ 6

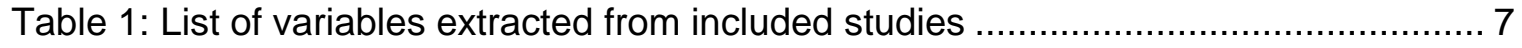

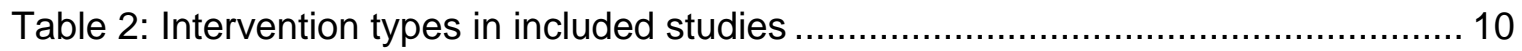

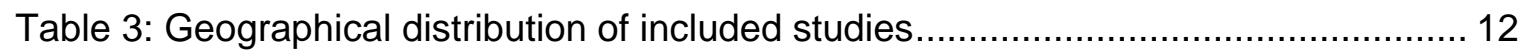

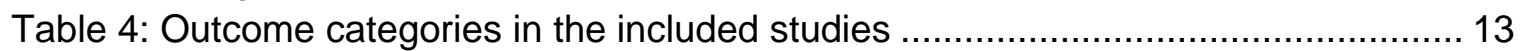

Table 5: Frequency of outcome categories in addition to latrine use in the included

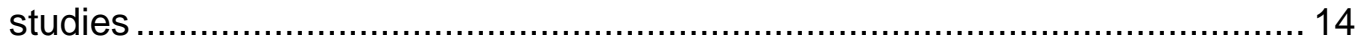

Table 6: Impact on latrine use and coverage from included experimental studies ......... 15

Table 7: Barriers to latrine use examined in the included studies .................................. 19

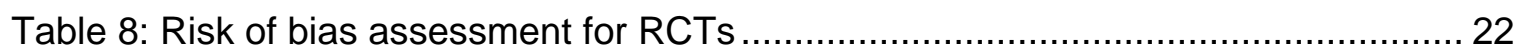

\section{Appendix tables}

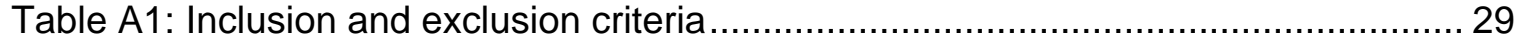




\section{List of abbreviations and acronyms}

CLTS Community-Led Total Sanitation

IEC Information, education and communication

PLUM Passive latrine use monitor

PRISMA Preferred Reporting Items for Systematic Reviews and Meta-Analyses

RCT Randomised controlled trial 


\section{Introduction}

Open defecation is a widespread and persistent health challenge in India, which is home to nearly 60 per cent of the global population that practises open defecation (WHO and UNICEF 2015). The health consequences of open defecation are long-lasting and lifethreatening. Chief among them is diarrhoea, which is responsible for 188,000 deaths of children under age 5 in India annually (UNICEF India 2016). This can be caused by microbial contamination of water through faecal run-off. Diseases caused by faeces such as trachoma, soil-transmitted helminthiases and schistosomiasis - can be transmitted directly or indirectly to humans through contaminated fluids, fingers, skin and foods (Mara et al. 2010). Disease transmission and inadequate dietary intake facilitated by open defecation also cause chronic undernutrition (stunting) in children, which diminishes cognitive abilities, lowers school productivity and diminishes human capital (Spears and Lamba 2015).

Open defecation has other consequences, too. It threatens the dignity of women, who often choose to relieve themselves at night for privacy, leaving them vulnerable to physical attacks, including molestation, and threats such as snakebite (UNICEF India 2016; Hulland et al. 2015b; Sahoo et al. 2015; Routray et al. 2015).

Although India made significant strides during the Millennium Development Goal period (1990-2015), reducing open defecation by 31 per cent, the stark reality remains that nearly half (44 per cent) of India's more than 1 billion people defecate in the open (WHO and UNICEF 2015). The World Bank (2011) estimates the combined economic consequences of inadequate sanitation - in terms of health-related impacts, domestic water-related impacts and cost-of-time impacts from shared toilets and potential lost tourism revenue - at US\$53.8 billion, or about 6.4 per cent of India's gross domestic product.

The high concentration of humanity, disease and open defecation represents a veritable sanitation crisis, particularly in rural areas. In 2014, the national government invested approximately US\$9.4 billion in the Swachh Bharat (Clean India) Mission to eliminate open defecation and provide toilets to every household by October 2019. The Swachh Bharat Mission follows similar national sanitation programmes such as Nirmal Bharat Abhiyan, which was preceded by the Total Sanitation Campaign and Central Rural Sanitation Programme. A key aim of the Swachh Bharat Mission is to increase latrine coverage in rural areas, where 90 per cent of households do not have toilets.

Through a focus on latrine use rather than coverage or construction, this study draws attention to a critical knowledge gap in the literature and aims to identify potential ways forward. We expect this study will be useful for researchers, policymakers and programme managers who are interested in the evidence on latrine non-use in rural areas, particularly in rural India. This report is organised in five sections: this introduction, followed by methods, results, discussion and conclusion.

\subsection{Objectives}

The overall objective of this scoping study is to examine the state of quantitative evidence on latrine use in rural India. The results are expected to inform the focus of 
3ie's thematic window on promoting latrine use in rural India. In this regard, we describe documented interventions and their effects on latrine use, as well as the relevant determinants and barriers. Additionally, we consider the risk of bias in the impact evaluation studies.

\subsection{Determinants of latrine use}

It is clear that latrine coverage alone does not lead to increased use of latrines or reduced faecal exposure. Latrine use depends on a multitude of factors that are affected by both supply- and demand-driven contextual factors. The literature suggests a variety of causes for non-use. Sociocultural beliefs, especially related to ritual purity, disgust, caste and latrine pits are a persistent barrier to latrine use, as emptying a latrine pit can be seen by higher-caste Indians as the remit of lower castes, despite such 'manual scavenging' being outlawed in India (Coffey et al. 2014; Human Rights Watch 2014; Gupta et al. 2016). In particular, gendered determinants that encourage open defecation - such as masculinity, strength, intra-household power, health and convenience - are specific psychosocial beliefs and factors which mediate an individual's decision to use a latrine.

Additionally, the perceived latrine cost and availability of options is another determinant of the decision to use a latrine (Coffey et al. 2014; Shah et al. 2013; Dreibelbis et al. 2015). Demographic characteristics such as sex and age are also associated with differential latrine use patterns (Coffey et al. 2014; Barnard et al. 2013; Routray et al. 2015). Infrastructure quality and design are also intimately tied to one's decision to use a latrine (Routray et al. 2015; Shah et al. 2013). Government-sponsored latrines are especially prone to disuse, repurposing of materials or use as storage rooms.

However, none of these causes alone explains non-sustained use sufficiently, and any programme that aims to increase latrine use must address multiple aspects of use. In a multicountry analysis, UNICEF and WHO (2015a) found that countries far poorer than India, such as Malawi, Afghanistan, Kenya and Bangladesh, have lower rates of open defecation, demonstrating that poverty alone cannot explain India's open defecation challenge. Coffey et al. (2014) call this the 'triple challenge' of rural Indian sanitation widespread open defecation, high population density and low demand for latrine use.

\subsection{Demand-driven approaches to ending open defecation}

A variety of approaches have been used to address the high rates of open defecation, despite the availability or existence of toilets. ${ }^{1}$ Demand-driven approaches to sanitation have typically focused on community mobilisation efforts. In this regard, Community-Led Total Sanitation (CLTS), developed by Kamal Kar in the late 1990s, is the most common approach taken towards ending open defecation. Although CLTS has been used in 66 countries, its effectiveness in low- and middle-income countries has been highly variable (Sigler et al. 2015). In India, its effectiveness has been described as 'mixed' (Chambers

\footnotetext{
${ }^{1}$ Throughout this review, we distinguish demand-driven and supply-driven approaches to latrine use. Supply approaches include the provision of enabling infrastructure (e.g. toilet construction) and finance (e.g. incentives or subsidies for toilet construction). Demand approaches aim to increase demand for latrines or use of latrines (e.g. community mobilisation and health education, shaming and disgust triggering).
} 
2009). Kar and Chambers (2008) point to the limited effectiveness of CLTS in dense, diverse settings.

Another demand-driven approach is community health clubs. They were first established in Zimbabwe and include, amongst others, weekly health promotion classes, commitment devices (club members promising small health and hygiene improvements, such as covering drinking water, before the next class), health songs and slogans, a certificate of full attendance and home visits arranged amongst club members for monitoring (Waterkeyn and Cairncross 2005). In Zimbabwe, these clubs resulted in significant increases in latrine coverage, burial of faeces and handwashing amongst treatment groups.

Other demand-driven approaches to sanitation have typically focused on triggering shame and disgust, providing knowledge and developing action plans (Sigler et al. 2015). In this regard, information, education and communication (IEC) campaigns, often in tandem with community mobilisation activities, have been used frequently to develop individuals' intrinsic motivation to use a toilet after demonstrating the harmful effects of open defecation. ${ }^{2}$ A systematic review examining factors affecting adoption of water, sanitation and hygiene technologies found that frequent, personal contact with a health promoter over time was the most influential programme factor associated with behaviour change (Hulland et al. 2015a).

\subsection{Emergence of behavioural science in demand-driven approaches to sanitation}

New approaches are being pioneered in behavioural science to end open defecation. As discussed above, traditional demand-driven approaches have focused on conscious, reflective systems in which individuals deliberate and think through alternative choices before making a decision (Neal and Vujcic 2016). Others have argued that the focus should be on leveraging individuals' automatic decision-making processes.

These automatic decisions are taken without individuals being consciously aware of the process. For instance, a well-practised driver does not need to consider the series of steps required to drive a car, as these actions are ingrained in her automatic decisionmaking processes. A novice driver, however, needs to consider each step consciously. The focus on automatic decision-making is influenced by findings in public health (World Bank 2014; Neal and Vujcic 2016). For instance, campaigns providing information about the benefits or harmful effects of a particular decision, such as smoking, have been ineffective in reducing harms to health (Marteau et al. 2012). This is because most behaviour in daily life is automatic and non-deliberative (Marteau et al. 2012; World Bank 2014).

\footnotetext{
${ }^{2}$ The combination of CLTS and incentives for toilet construction contrasts with a core tenet of CLTS, which argues for mobilisation without external subsidies (Kar and Chambers 2008).
} 
Drawing from the behavioural sciences ${ }^{3}$ - disciplines that examine human and animal behaviour through disciplined scientific experimentation - other emerging evidencebased theoretical approaches are being applied in sanitation studies as well. The following are a few examples:

- The Theory of Reasoned Action postulates that beliefs that a particular behaviour will yield a particular outcome are the immediate antecedents to behaviour (Fishbein and Ajzen 1975). CLTS has employed aspects of this theory (Sigler et al. 2015).

- The Risks, Attitudes, Norms, Abilities, Self-Regulation model draws on theories from health psychology and postulates a multidimensional framework to examine behaviour. It includes perceptions, attitudes, beliefs, abilities and self-regulation as the main drivers of behaviour change and habit formation (Mosler 2012).

- The Integrated Behavioural Model for Water, Sanitation and Hygiene model argues that behaviour is a product of three intersecting dimensions (contextual, psychosocial and technological). These dimensions are further contextualised using three levels - the societal, the communal and the interpersonal (Dreibelbis et al. 2013).

- The SaniFOAM framework considers the target behaviour, target population and the determinants that influence them (Devine 2009).

Many of these theories share overlapping constructs and ideas. The development of a behaviour change theory is essentially an iterative process that builds upon previous findings. We believe that these overlapping constructs can be used to understand the antecedents of latrine use, which constitute prime targets for behaviour change interventions.

\section{Methods}

To understand the state of quantitative evidence on latrine use in rural India, we discuss findings from studies found through a systematic search. We also convened two consultative workshops and undertook a field visit to a rural Indian setting to inform our understanding.

\subsection{Search and screening strategy}

To ensure that we captured quantitative studies on latrine use in rural India, we developed a deliberately broad set of inclusion criteria. We captured studies where latrine use was a primary, secondary or tertiary outcome and were conducted in rural India. Studies self-identified the definition of 'rural'; we did not use any set criteria for considering a community rural.

Our populations of interest, rural Indians, were not age restricted, as we were interested in latrine use by children and adults. The units of analysis were the individual, household,

\footnotetext{
${ }^{3}$ We are unaware of any standard definition of behavioural science. The term 'behavioural insights' is used to refer to findings from economics and psychology about human decisionmaking but is sometimes conflated with behavioural science, notable in President Barack Obama's executive order, 'Using Behavioral Science Insights to Better Serve the American People'. Thus, we settle for the general definition given above.
} 
community or village. We searched only for quantitative studies or reviews, which comprised quantitatively collected data, reported statistical analyses (e.g. t-tests and chisquare tests) and investigated relationships between a programme or a policy and its effect on latrine use.

We included quantitative studies because we aimed to assess the extent of quantified evidence available on the causal and correlational factors associated with latrine use. Qualitative studies, while central to understanding latrine use behaviour, merit a separate review; these were deemed to be outside the scope of this paper. We also included mixed-method studies, which are defined as having components of both qualitative and quantitative analysis of data that met our criteria. The search on 17 March 2016 included only English-language studies and was restricted to completed studies from the last 20 years.

Studies were excluded if they did not assess latrine use as an outcome, were not conducted in rural India, were entirely qualitative or only reported descriptive statistics when presenting statistical analyses. After deciding on our population, intervention, comparator, outcomes and study designs, we developed a search strategy comprising free text and subject heading terms that were employed in the following peer-reviewed databases: OVID Medline, PsycINFO, Global Health, Embase, ProQuest, GreenFILE, Scopus, CAB Abstracts and Web of Science (see Appendix A). ${ }^{4}$ We searched for grey literature separately due to the inconsistent and limited search functions of grey literature databases. The search included the following grey literature sources: Grey Literature Report, Ministry of Drinking Water and Sanitation (Government of India), Open Grey, UNICEF, World Health Organization, World Bank Open Knowledge Repository and RTI.org.

The primary outcome is latrine use, defined as disposal of human excreta using a latrine. ${ }^{5}$ We included all types of latrines, such as pit latrines without a slab, shared latrines, pour flush latrines and ventilated improved latrines. Studies measuring outcomes related to anthropometry, health and open defecation were not included if they did not also assess latrine use. Though open defecation is the converse of latrine use, we believe that focusing exclusively on open defecation as a proxy for latrine use is less accurate than including studies that focus on and triangulate measurements of latrine use. Reactivity and social desirability bias are inherent in reporting both latrine use and open defecation, but triangulating measures for latrine use provide more confidence in the validity of measurement results than focusing on open defecation alone.

\subsection{Data extraction and analysis}

We imported references into Endnote $X 7$ and created two copies of the reference library. The Preferred Reporting Items for Systematic Reviews and Meta-Analyses (PRISMA) diagram of the study selection process is presented in Figure 1. Two researchers independently reviewed and screened search results.

\footnotetext{
${ }^{4}$ Appendix A also presents the full search strategy for one database.

${ }^{5}$ To ensure the search was sufficiently broad, search terms included 'latrine', 'lavatory', 'open defecation', 'water closet' and 'excreta' using various Boolean operators.
} 
At each stage, the two researchers compared their results, resolved discrepancies and achieved consensus before moving to the next stage. Data was extracted on a list of variables presented in Table 1.

After extracting data, we analysed main themes and synthesised findings in a narrative. Data on interventions and outcomes are presented using frequency tables. ${ }^{6}$ We did not conduct a statistical meta-analysis of study results due to the lack of studies and unclear nature of the interventions and outcomes among the included studies. ${ }^{7}$

\section{Figure 1: PRISMA diagram of study selection process}

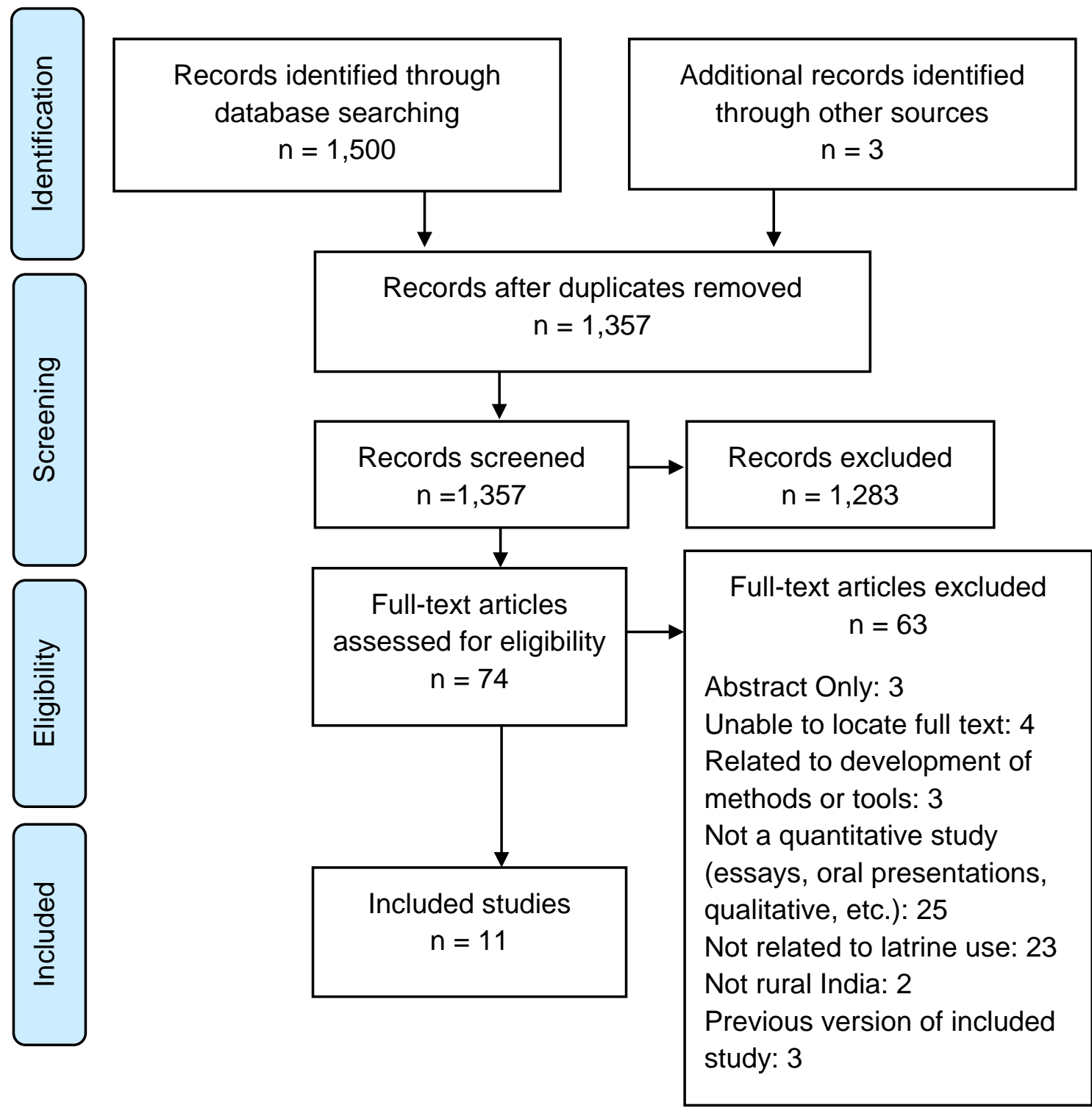

\footnotetext{
${ }^{6} \mathrm{~A}$ frequency table here is a two-dimensional representation of data in which values are represented by colors, differentiated by frequency, to ease visualisation and interpretation.

${ }^{7}$ We are aware that meta-analysis can even be conducted with just two studies, and in cases of substantial heterogeneity between studies (Ioannidis et al. 2008). However, we felt that a quantitative summary measure of the few included studies would yield an uncertain estimate, with limited interpretative value.
} 
Table 1: List of variables extracted from included studies

\begin{tabular}{|c|c|}
\hline Study variable & Description \\
\hline Location & Geographical setting of the study \\
\hline Design & Quantitative design of study \\
\hline Objective & Primary and secondary objectives of study \\
\hline Sample characteristics & $\begin{array}{l}\text { Composition of study sample (i.e. age, } \\
\text { size, sex, socioeconomic status) }\end{array}$ \\
\hline Intervention description & Intervention characteristics \\
\hline Primary unit of analysis & Major entity being analysed in study \\
\hline Other unit of analysis (if applicable) & Secondary entity being analysed in study \\
\hline Selection of main units & $\begin{array}{l}\text { Method through which unit(s) of analysis } \\
\text { were chosen }\end{array}$ \\
\hline Barriers to latrine use & $\begin{array}{l}\text { Specific obstacles to the adoption of } \\
\text { latrines identified in the study, if any }\end{array}$ \\
\hline Data collection methods & $\begin{array}{l}\text { Tools and processes employed in } \\
\text { collecting data }\end{array}$ \\
\hline Quantitative analytical methods & Statistical tests and related assumptions \\
\hline Transparency and accountability & $\begin{array}{l}\text { Implications for government processes or } \\
\text { procedures, if any }\end{array}$ \\
\hline Cost-effectiveness & $\begin{array}{l}\text { Findings of relative cost of different } \\
\text { interventions and/or products, if any }\end{array}$ \\
\hline Adequacy of funds & $\begin{array}{l}\text { Findings related to perceptions of the } \\
\text { adequacy of national sanitation program } \\
\text { subsidies for toilet construction }\end{array}$ \\
\hline Knowledge, attitudes, and practices & $\begin{array}{l}\text { Beliefs, habits and behaviours related to } \\
\text { latrine use (e.g. about safety, gendered } \\
\text { norms, purity) }\end{array}$ \\
\hline Acceptability of intervention & $\begin{array}{l}\text { Appropriateness related to beneficiary } \\
\text { acceptance of intervention }\end{array}$ \\
\hline Maintenance of latrine & $\begin{array}{l}\text { Cleaning and upkeep of latrines, including } \\
\text { construction and quality aspects }\end{array}$ \\
\hline $\begin{array}{l}\text { Political empowerment of vulnerable } \\
\text { groups }\end{array}$ & $\begin{array}{l}\text { Enfranchisement and increased decision- } \\
\text { making power for vulnerable groups such } \\
\text { as women and adolescent girls, the } \\
\text { elderly and individuals with disabilities. }\end{array}$ \\
\hline Psychological stress & Diminished mental wellbeing \\
\hline Coverage and access & Coverage and access to latrines \\
\hline Beneficiary-informed decision-making & $\begin{array}{l}\text { Findings related to increased decision- } \\
\text { making power for target population, if any }\end{array}$ \\
\hline Latrine use & Disposal of human excreta in a latrine \\
\hline
\end{tabular}

\subsection{Risk of bias in randomised controlled trials}

To assess risk of bias of the four included randomised evaluations, we used a tool described by Waddington and others (2014) and a checklist for assessing the validity of randomised controlled trials (RCTs) used by the Coalition for Evidence-Based Policy 
(2010). Two reviewers independently scored all studies, resolved discrepancies and achieved consensus to produce the final ratings.

We performed this additional risk of bias assessment to provide a more detailed analysis of causal studies, which are the prime focus of this review:

- High risk: We identifed studies as having a high risk of bias if one or more bias categories were not addressed. This included instances when comparison groups were not matched on observables, differences in covariates were not accounted for in multivariate analysis or there were serious threats to the validity of the statistical procedure used to deal with attribution, or where there was evidence for spillovers or contamination, and reporting biases were evident.

- Medium risk: We identified studies as having a medium risk of bias when at least one bias category was unclear. These included threats to methods used for causal attribution, smaller risks of spillovers or contamination (arising from inadequate description of intervention or comparison groups or possibilities for interaction between groups, such as when they were from the same community), or possible reporting biases.

- Low risk: We identified studies that addressed all bias categories as having a low risk of bias.

\subsection{Consultative workshops and field visit}

To inform this scoping paper, we convened two consultation workshops and invited experts from the Indian sanitation and behavioural science sectors. Participants represented non-governmental organisations, multilateral organisations and universities. The first workshop in April 2016 explored and analysed findings from the field on issues related to sanitation in rural India. The second workshop in July 2016 focused on behavioural science approaches to sanitation interventions. Additionally, we undertook a field visit to rural Rajasthan to better understand some of the barriers and determinants of latrine use in rural settings.

\subsection{Limitations}

Two limitations of this study are worth noting. The focus on rural India is a potential limitation, as it restricts the potential of findings from other contexts. Given that the highest concentration of open defecation in the world is in rural India, we believe that this is a high-priority area for further research that must begin with a survey of existing quantitative literature, followed by a review of qualitative literature, leading to an assessment of what we know and what we do not know. This review is directed at the first part of this process.

The lack of a meta-analysis in this review can be considered a potential limitation, as meta-analysis would have provided a summary of the effect of certain interventions on latrine use. However, we believed that this would not have been useful, considering the lack of literature on what interventions have been implemented and evaluated to promote latrine use in rural India. The lack of literature does not preclude a meta-analysis, but it limits the interpretability of the results. 


\section{Results}

\subsection{Methods of included studies}

From the 1,503 studies identified from searching peer-reviewed and grey literature sources, 11 quantitative studies, including three mixed-methods studies, met our inclusion criteria (Figure 1). Data were extracted from the studies on a number of variables (see Table 1). The complete list of variables can be found in Appendix $B$, and Appendix $C$ provides the list of included studies.

\subsubsection{Study design, coverage and sample size}

Seven studies were non-experimental studies, and the remaining four were RCTs. Among the non-experimental studies, three of the seven (43 per cent) use a mixedmethods approach, using qualitative and quantitative data to estimate and understand latrine use (Coffey et al. 2014; Hirve et al. 2015; O'Reilly et al. 2015). Two of the RCT studies (Pattanayak et al. 2009; Dickinson 2008) use data from the same impact evaluation, but were considered as separate studies because they focus on different outcome variables. Similarly, three other conduct their analyses based on the same sample population but examine different outcomes (Barnard et al. 2013; Clasen et al. 2014; Majorin et al. 2014).

Sample sizes ranged from approximately 150-500 households for non-experimental studies and 1,000-3,000 households for experimental studies, with one exception: Coffey and others (2014) sampled 3,235 households. Attrition rates reported by Pattanayak and others (2009) are approximately 2-4 per cent for treatment and control groups, whereas for Patil and others (2014), around 15 per cent. However, Patil and others (2014) report non-systematic attrition, whereas Pattanayak and others (2009) and Dickinson (2008) do not present data on the balance of attrited and non-attrited samples.

\subsubsection{Data collection methods}

All 11 included studies used primary data collected through household surveys. Other than household surveys, latrine use was measured though spot checks of latrines (Barnard et al. 2013; Majorin et al. 2014), ethnography (O'Reilly et al. 2015), household member interviews (Coffey et al. 2014), observational methods (Zacharia and Shordt 2004) and passive latrine use monitors (PLUMs) for sensor monitoring (e.g. O'Reilly et al. 2015).

\subsection{Latrine use interventions}

\subsubsection{Types of interventions}

The 11 included studies focus on six types of interventions. Table 2 presents a brief description of each intervention. Studies are categorised based on the description of the intervention reported; thus, the intervention categories are not mutually exclusive. Interventions aimed at increasing latrine use in rural India are usually part of a larger sanitation programme with multiple components.

The most frequent interventions appearing in the included studies were subsidies and IEC campaigns. Four studies were conducted without a clear definition of an intervention (Banda et al. 2007; Coffey et al. 2014; Hirve et al. 2015; O'Reilly et al. 2015). 
Table 2: Intervention types in included studies

\begin{tabular}{|c|c|c|}
\hline Intervention & Brief description & Study (location) \\
\hline $\begin{array}{l}\text { Community } \\
\text { mobilisation, } \\
\text { including } \\
\text { CLTS } \\
\text { (2 studies) }\end{array}$ & $\begin{array}{l}\text { Bringing together members of a } \\
\text { community to achieve a specified } \\
\text { outcome. CLTS is broadly defined as an } \\
\text { approach to achieve sustained } \\
\text { behaviour change amongst rural people } \\
\text { by a process of 'triggering' disgust and } \\
\text { shame, leading to spontaneous and } \\
\text { long-term abandonment of open } \\
\text { defecation practices. The original } \\
\text { approach focuses on 'empowering local } \\
\text { people to analyse the extent and risk of } \\
\text { environmental pollution caused by open } \\
\text { defecation' (Kar 2003). }\end{array}$ & $\begin{array}{l}\text { - Clasen et al. } 2014 \\
\text { (Odisha) } \\
\text { - Dickinson } 2008 \text { (Odisha) }\end{array}$ \\
\hline $\begin{array}{l}\text { Construction } \\
\text { of latrines } \\
\text { (1 study) }\end{array}$ & $\begin{array}{l}\text { Supply-driven intervention aimed at } \\
\text { providing communities with household } \\
\text { or community latrines. This intervention } \\
\text { can also target schools, workplaces or } \\
\text { childcare centres. }\end{array}$ & $\begin{array}{l}\text { - Zacharia and Shordt } \\
2004 \text { (Kerala) }\end{array}$ \\
\hline $\begin{array}{l}\text { Subsidies } \\
\text { (6 studies) }\end{array}$ & $\begin{array}{l}\text { A specified amount of money is granted } \\
\text { by the government, the state or a } \\
\text { development agency to support } \\
\text { households or communities in meeting } \\
\text { the costs related to latrine construction. } \\
\text { The main feature of this intervention is } \\
\text { to keep the price of latrines or related } \\
\text { services affordable. }\end{array}$ & $\begin{array}{l}\text { - Barnard et al. } 2013 \\
\text { (Odisha) } \\
\text { - Clasen et al. } 2014 \\
\text { (Odisha) } \\
\text { - Dickinson } 2008 \text { (Odisha) } \\
\text { - Majorin et al. } 2014 \\
\text { (Odisha) } \\
\text { - Patil et al. } 2014 \text { (Madhya } \\
\text { Pradesh) } \\
\text { - Pattanayak et al. } 2009 \\
\text { (Odisha) }\end{array}$ \\
\hline $\begin{array}{l}\text { IEC } \\
\text { campaigns } \\
\text { (5 studies) }\end{array}$ & $\begin{array}{l}\text { Broadly defined as an approach which } \\
\text { attempts to change or reinforce a set of } \\
\text { behaviours in a target audience (usually } \\
\text { households or individuals) regarding a } \\
\text { specific problem related to sanitation in } \\
\text { general and open defecation in } \\
\text { particular. The aim is to raise } \\
\text { awareness of the target population, with } \\
\text { subsequent expectations that its } \\
\text { behaviours will change positively. This } \\
\text { includes specific forms of IEC (medium- } \\
\text { term campaigns focused on hygiene } \\
\text { education/promotion through training, } \\
\text { home visits and mass activities). }\end{array}$ & $\begin{array}{l}\text { - } \text { Barnard et al. } 2013 \\
\text { (Odisha) } \\
\text { - Dickinson } 2008 \text { (Odisha) } \\
\text { - } \text { Majorin et al. } 2014 \\
\text { (Odisha) } \\
\text { - Pattanayak et al. } 2009 \\
\text { (Odisha) } \\
\text { - Zacharia and Shordt } \\
2004 \text { (Kerala) }\end{array}$ \\
\hline
\end{tabular}




\begin{tabular}{|c|c|c|}
\hline Intervention & Brief description & Study (location) \\
\hline $\begin{array}{l}\text { No specific } \\
\text { intervention } \\
\text { (4 studies) }\end{array}$ & $\begin{array}{l}\text { No specific intervention is described. } \\
\text { These studies typically present the } \\
\text { results of a single-point, cross-sectional } \\
\text { survey of latrine use habits, and related } \\
\text { behaviour. }\end{array}$ & $\begin{array}{l}\text { - Banda et al. } 2007 \text { (Tamil } \\
\text { Nadu) } \\
\text { - Coffey et al. } 2014 \text { (Bihar, } \\
\text { Haryana, Madhya } \\
\text { Pradesh, Rajasthan and } \\
\text { Uttar Pradesh) } \\
\text { - Hirve et al. } 2015 \\
\text { (Maharashtra) } \\
\text { - O'Reilly et al. } 2015 \text { (West } \\
\text { Bengal and Himachal } \\
\text { Pradesh) }\end{array}$ \\
\hline
\end{tabular}

\subsubsection{Frequency of interventions}

Table 3 presents the frequency of latrine use-related interventions in rural India, based on the 11 studies in this review, showing the types of interventions the studies investigate. One study can map to more than one type of intervention. For instance, if a study examines IEC and community mobilisation, then both interventions are reflected in the appropriate columns. Amongst India's 29 states, Odisha is studied most frequently (five studies). Many states with high open defecation rates - such as Bihar, Madhya Pradesh, Uttar Pradesh and Jharkhand - are poorly studied or not studied at all. There are also few studies in states with low open defecation rates - such as Assam, Manipur, Meghalaya and Mizoram - despite success stories from these locations that could be useful for lower-performing states. 
Table 3: Geographical distribution of included studies

\begin{tabular}{|c|c|c|c|c|c|c|c|c|c|}
\hline & & \multicolumn{2}{|c|}{ Key figures } & \multicolumn{6}{|c|}{ Number of studies examining the following interventions } \\
\hline & & $\begin{array}{l}\text { Household toilet } \\
\text { coverage (\%) }\end{array}$ & $\begin{array}{l}\text { Open defecation-free } \\
\text { villages in state (\%) }\end{array}$ & $\begin{array}{l}\begin{array}{l}\text { Community Mobilisation } \\
\text { (including CLTS) }\end{array} \\
\end{array}$ & $\begin{array}{l}\text { Latr } \\
\text { con: }\end{array}$ & tion & Subsidies & IEC campaign & None \\
\hline 0 & Nationwide & 54.61 & 13.27 & 0 & & & 0 & 0 & 0 \\
\hline 1 & Andhra Pradesh & 47.29 & 4.64 & 0 & & & 0 & 0 & 0 \\
\hline 2 & Arunachal Pradesh & 70.61 & 16.02 & 0 & & & 0 & 0 & 0 \\
\hline 3 & Assam & 56.06 & 0.84 & 0 & & & 0 & 0 & 0 \\
\hline 4 & Bihar & 25.26 & 0.71 & 0 & & & 0 & 0 & 1 \\
\hline 5 & Chhattisgarh & 56.52 & 22.76 & 0 & & & 0 & 0 & 0 \\
\hline 6 & Goa & 76.08 & 0 & 0 & & & 0 & 0 & 0 \\
\hline 7 & Gujarat & 79.41 & 34.28 & 0 & & & 0 & 0 & 0 \\
\hline 8 & Haryana & 87.42 & 37.44 & 0 & & & 0 & 0 & 1 \\
\hline 9 & Himachal Pradesh & 97.18 & 54.61 & 0 & & & 0 & 0 & 1 \\
\hline 10 & Jammu and Kashmir & 33.41 & 0.43 & 0 & & & 0 & 0 & 0 \\
\hline 11 & Jharkhand & 40.52 & 3.85 & 0 & & & 0 & 0 & 0 \\
\hline 12 & Karnataka & 59.4 & 12.46 & 0 & & & 0 & 0 & 0 \\
\hline 13 & Kerala & 96.35 & 7.41 & 0 & & & 0 & 1 & 0 \\
\hline 14 & Madhya Pradesh & 47.4 & 10.8 & 0 & & & 1 & 0 & 1 \\
\hline 15 & Maharashtra & 66.17 & 26.17 & 0 & & & 0 & 0 & 1 \\
\hline 16 & Manipur & 81.04 & 2.87 & 0 & & & 0 & 0 & 0 \\
\hline 17 & Meghalaya & 82.47 & 38.26 & 0 & & & 0 & 0 & 0 \\
\hline 18 & Mizoram & 84.75 & 13.06 & 0 & & & 0 & 0 & 0 \\
\hline 19 & Nagaland & 66.75 & 11.1 & 0 & & & 0 & 0 & 0 \\
\hline 20 & Odisha & 32.8 & 4.1 & 2 & & & 5 & 5 & 0 \\
\hline 21 & Punjab & 78.97 & 11.75 & 0 & & & 0 & 0 & 0 \\
\hline 22 & Rajasthan & 60.93 & 22.33 & 0 & & & 0 & 0 & 1 \\
\hline 23 & Sikkim & 100 & 100 & 0 & & & 0 & 0 & 0 \\
\hline 24 & Tamil Nadu & 62.92 & 12.28 & 0 & & & 0 & 0 & 1 \\
\hline 25 & Telangana & 42.13 & 9.99 & 0 & & & 0 & 0 & 0 \\
\hline 26 & Tripura & 75 & 0.87 & 0 & & & 0 & 0 & 0 \\
\hline 27 & Uttar Pradesh & 44.2 & 1.89 & 0 & & & 0 & 0 & 1 \\
\hline 28 & Uttarakhand & 86.42 & 18.23 & 0 & & & 0 & 0 & 0 \\
\hline 29 & West Bengal & 77.27 & 21.82 & 0 & & & 0 & 0 & 1 \\
\hline \multirow{8}{*}{\multicolumn{4}{|c|}{$\begin{array}{l}\text { Note: Coverage and open defection-free statistics for 2016-2017 } \\
\text { are official data from http://sbm.gov.in/sbmdashboard/Default.aspx. }\end{array}$}} & \multicolumn{6}{|c|}{ Frequency of studies } \\
\hline & & & & \multicolumn{2}{|c|}{ Household toilet coverage } & \multicolumn{2}{|c|}{$\begin{array}{l}\text { Percentage of open } \\
\text { defecation-free villages }\end{array}$} & \multicolumn{2}{|c|}{ Number of studies } \\
\hline & & & & \multirow{2}{*}{\multicolumn{2}{|c|}{$\begin{array}{c}100 \\
80 \\
\end{array}$}} & \multicolumn{2}{|r|}{100} & \multicolumn{2}{|c|}{0} \\
\hline & & & & & & \multirow{2}{*}{\multicolumn{2}{|c|}{$\frac{80}{60}$}} & \multicolumn{2}{|c|}{1} \\
\hline & & & & \multicolumn{2}{|l|}{60} & & & \multicolumn{2}{|c|}{2} \\
\hline & & & & \multicolumn{2}{|l|}{$\frac{40}{20}$} & \multicolumn{2}{|r|}{40} & & \\
\hline & & & & \multirow{2}{*}{\multicolumn{2}{|c|}{$\frac{20}{0}$}} & \multirow{2}{*}{\multicolumn{2}{|c|}{$\frac{20}{0}$}} & \multicolumn{2}{|c|}{4} \\
\hline & & & & & & & & & \\
\hline
\end{tabular}




\subsection{Latrine use outcomes}

\subsubsection{Types of outcomes}

Based on the 11 included studies, Table 4 presents the key outcome variables reported in addition to latrine use. These additional outcomes are presented to understand possible correlates of latrine use.

Table 4: Outcome categories represented in the included studies

\begin{tabular}{|c|c|c|}
\hline $\begin{array}{l}\text { Outcome } \\
\text { category }\end{array}$ & Outcome and brief description & Study (location) \\
\hline $\begin{array}{l}\text { Infrastructure } \\
\text { (11 studies) }\end{array}$ & $\begin{array}{l}\text { Coverage of and access to } \\
\text { latrines includes latrines } \\
\text { constructed through public or } \\
\text { private funding. } \\
\text { Maintenance of latrines includes } \\
\text { services or individual actions to } \\
\text { maintain functionality and } \\
\text { desirability of latrines. }\end{array}$ & $\begin{array}{l}\text { - Dickinson } 2008 \text { (Odisha) } \\
\text { - Zacharia and Shordt } 2004 \\
\text { (Kerala) } \\
\text { - Pattanayak et al. } 2009 \text { (Odisha) } \\
\text { - Barnard et al. } 2013 \text { (Odisha) } \\
\text { - Majorin et al. } 2014 \text { (Odisha) } \\
\text { - Patil et al. } 2014 \text { (Madhya } \\
\text { Pradesh) } \\
\text { - O'Reilly et al. } 2015 \text { (West } \\
\text { Bengal and Himachal Pradesh) } \\
\text { - Banda et al. } 2007 \text { (Tamil Nadu) } \\
\text { - Coffey et al. } 2014 \text { (Bihar, } \\
\text { Haryana, Madhya Pradesh, } \\
\text { Rajasthan, Uttar Pradesh) } \\
\text { - Hirve et al. } 2015 \text { (Maharashtra) } \\
\text { - Clasen et al. } 2014 \text { (Odisha) }\end{array}$ \\
\hline $\begin{array}{l}\text { Psychosocial } \\
\text { (6 studies) }\end{array}$ & $\begin{array}{l}\text { Factors related to psychological } \\
\text { and behavioural processes, } \\
\text { including psychosocial stress; } \\
\text { knowledge, attitudes and } \\
\text { practices related to latrine use; } \\
\text { beneficiary-informed decision- } \\
\text { making; empowerment of } \\
\text { vulnerable groups; and social } \\
\text { interactions and peer effects in } \\
\text { driving adoption of latrines. }\end{array}$ & $\begin{array}{l}\text { - Banda et al. } 2007 \text { (Tamil Nadu) } \\
\text { - Barnard et al. } 2013 \text { (Odisha) } \\
\text { - Coffey et al. } 2014 \text { (Bihar, } \\
\text { Haryana, Madhya Pradesh, } \\
\text { Rajasthan and Uttar Pradesh) } \\
\text { - Hirve et al. } 2015 \text { (Maharashtra) } \\
\text { - Dickinson } 2008 \text { (Odisha) } \\
\text { - Patil et al. } 2014 \text { (Madhya } \\
\text { Pradesh) }\end{array}$ \\
\hline $\begin{array}{l}\text { Health } \\
\text { (3 studies) }\end{array}$ & $\begin{array}{l}\text { Factors related to physical health } \\
\text { and disease including diarrhoea, } \\
\text { nutrition, malaria, mortality, } \\
\text { enteropathy and soil-transmitted } \\
\text { helminthiases, amongst others. }\end{array}$ & $\begin{array}{l}\text { - Dickinson } 2008 \text { (Odisha) } \\
\text { - Patil et al. } 2014 \text { (Madhya } \\
\text { Pradesh) } \\
\text { - Clasen et al. } 2014 \text { (Odisha) }\end{array}$ \\
\hline
\end{tabular}

\subsubsection{Frequency of outcomes}

Table 5 presents the frequency of studies, organised by outcome categories in addition to latrine use in the included studies. The outcome categories are not mutually exclusive. 
Table 5: Frequency of outcome categories in addition to latrine use in the included studies

\begin{tabular}{|c|c|c|c|c|c|c|}
\hline \multirow[t]{2}{*}{ SI } & \multirow[t]{2}{*}{ State } & \multicolumn{2}{|c|}{ Key figures } & \multicolumn{3}{|c|}{$\begin{array}{c}\text { Number of studies examining the } \\
\text { following outcomes }\end{array}$} \\
\hline & & $\begin{array}{l}\text { Household } \\
\text { toilet } \\
\text { coverage (\%) }\end{array}$ & $\begin{array}{l}\text { Open } \\
\text { defecation- } \\
\text { free villages } \\
\text { in state (\%) }\end{array}$ & Infrastructure & Psychosocial & Health \\
\hline 0 & Nationwide & 54.61 & 13.27 & 0 & 0 & 0 \\
\hline 1 & Andhra Pradesh & 47.29 & 4.64 & 0 & 0 & 0 \\
\hline 2 & Arunachal Pradesh & 70.61 & 16.02 & 0 & 0 & 0 \\
\hline 3 & Assam & 56.06 & 0.84 & 0 & 0 & 0 \\
\hline 4 & Bihar & 25.26 & 0.71 & 1 & 1 & 0 \\
\hline 5 & Chhattisgarh & 56.52 & 22.76 & 0 & 0 & 0 \\
\hline 6 & Goa & 76.08 & 0 & 0 & 0 & 0 \\
\hline 7 & Gujarat & 79.41 & 34.28 & 0 & 0 & 0 \\
\hline 8 & Haryana & 87.42 & 37.44 & 1 & 1 & 0 \\
\hline 9 & Himachal Pradesh & 97.18 & 54.61 & 1 & 0 & 0 \\
\hline 10 & Jammu and Kashmir & 33.41 & 0.43 & 0 & 0 & 0 \\
\hline 11 & Jharkhand & 40.52 & 3.85 & 0 & 0 & 0 \\
\hline 12 & Karnataka & 59.4 & 12.46 & 0 & 0 & 0 \\
\hline 13 & Kerala & 96.35 & 7.41 & 1 & 0 & 0 \\
\hline 14 & Madhya Pradesh & 47.4 & 10.8 & 2 & 2 & 1 \\
\hline 15 & Maharashtra & 66.17 & 26.17 & 1 & 1 & 0 \\
\hline 16 & Manipur & 81.04 & 2.87 & 0 & 0 & 0 \\
\hline 17 & Meghalaya & 82.47 & 38.26 & 0 & 0 & 0 \\
\hline 18 & Mizoram & 84.75 & 13.06 & 0 & 0 & 0 \\
\hline 19 & Nagaland & 66.75 & 11.1 & 0 & 0 & 0 \\
\hline 20 & Odisha & 32.8 & 4.1 & 4 & 2 & 1 \\
\hline 21 & Punjab & 78.97 & 11.75 & 0 & 0 & 0 \\
\hline 22 & Rajasthan & 60.93 & 22.33 & 1 & 1 & 0 \\
\hline 23 & Sikkim & 100 & 100 & 0 & 0 & 0 \\
\hline 24 & Tamil Nadu & 62.92 & 12.28 & 1 & 1 & 0 \\
\hline 25 & Telangana & 42.13 & 9.99 & 0 & 0 & 0 \\
\hline 26 & Tripura & 75 & 0.87 & 0 & 0 & 0 \\
\hline 27 & Uttar Pradesh & 44.2 & 1.89 & 0 & 0 & 0 \\
\hline 28 & Uttarakhand & 86.42 & 18.23 & 0 & 0 & 0 \\
\hline 29 & West Bengal & 77.27 & 21.82 & 1 & 0 & 0 \\
\hline
\end{tabular}

Note: Coverage and open defection-free statistics for 2016-2017 are official data from http://sbm.gov.in/sbmdashboard/Default.aspx.

\section{Frequency of studies}

\begin{tabular}{|c|c|c|}
\hline Coverage & Open defecation-free villages & Number of studies \\
\hline 100 & 100 & 0 \\
\hline 80 & 80 & 1 \\
\hline 60 & 60 & 2 \\
\hline 40 & 40 & 3 \\
\hline 20 & 20 & 4 \\
\hline 0 & 0 & 5 \\
\hline
\end{tabular}

\subsection{Impact of interventions on latrine use and coverage}

Only four of the included studies employ experimental methods to estimate the attributable impact of an intervention (Dickinson 2008; Pattanayak et al. 2009; Patil et al. 2014; Clasen et al. 2014). They examine latrine use through intention-to-treat estimates. Table 6 summarises their key impact findings, showing that the experimental studies, which looked at interventions similar to the Total Sanitation Campaign, resulted in 
increased latrine coverage and use. ${ }^{8}$ Patil and others (2014) show that the campaign resulted in significant increases in safe disposal of child faeces in Madhya Pradesh.

Table 6: Impact on latrine use and coverage from included experimental studies

\begin{tabular}{|c|c|c|c|c|}
\hline $\begin{array}{l}\text { Study and } \\
\text { intervention }\end{array}$ & $\begin{array}{l}\text { Latrine } \\
\text { coverage } \\
\text { difference }\end{array}$ & $\begin{array}{l}\text { Latrine use } \\
\text { difference }\end{array}$ & $\begin{array}{l}\text { Open defecation } \\
\text { rate } \\
\text { difference }\end{array}$ & $\begin{array}{l}\text { Child faeces } \\
\text { disposal } \\
\text { difference }\end{array}$ \\
\hline $\begin{array}{l}\text { Patil et al. } \\
2014 \\
\text { India's Total } \\
\text { Sanitation } \\
\text { Campaign } \\
\text { (IEC } \\
\text { campaign + } \\
\text { subsidy) }\end{array}$ & $\begin{array}{l}19 \% \text { higher } \\
\text { improved } \\
\text { sanitation }{ }^{9} \\
\text { coverage in } \\
\text { treatment } \\
\text { versus } \\
\text { control } \\
\text { villages }\end{array}$ & $\begin{array}{l}10 \% \text { higher household } \\
\text { latrine use in } \\
\text { treatment versus } \\
\text { control villages }\end{array}$ & $\begin{array}{l}\text { - } 9.5 \% \text { less } \\
\text { reported open } \\
\text { defecation for } \\
\text { men in treatment } \\
\text { versus control } \\
\text { villages } \\
10 \% \text { less } \\
\text { reported open } \\
\text { defecation for } \\
\text { women in } \\
\text { treatment versus } \\
\text { control villages } \\
\text { 5\% less reported } \\
\text { open defecation } \\
\text { for children in } \\
\text { treatment versus } \\
\text { control villages }\end{array}$ & $\begin{array}{l}9 \% \text { higher } \\
\text { reported correct } \\
\text { child faeces } \\
\text { disposal in } \\
\text { treatment } \\
\text { versus control } \\
\text { villages }\end{array}$ \\
\hline $\begin{array}{l}\text { Pattanayak } \\
\text { et al. } 2009 \\
\text { Intensified } \\
\text { IEC } \\
\text { campaign }\end{array}$ & $\begin{array}{l}28.7 \% \\
\text { greater } \\
\text { household } \\
\text { latrine } \\
\text { coverage in } \\
\text { treatment } \\
\text { versus } \\
\text { control } \\
\text { villages }\end{array}$ & $\begin{array}{l}\text { 25.6\% greater } \\
\text { latrine use for } \\
\text { men in treatment } \\
\text { versus control } \\
\text { villages } \\
23.2 \% \text { greater } \\
\text { latrine use for } \\
\text { women in } \\
\text { treatment versus } \\
\text { control villages } \\
11.3 \% \text { greater } \\
\text { latrine use for } \\
\text { children in } \\
\text { treatment versus } \\
\text { control villages }\end{array}$ & Not reported & Not reported \\
\hline $\begin{array}{l}\text { Dickinson } \\
2008\end{array}$ & $\begin{array}{l}24.7 \% \\
\text { greater } \\
\text { household } \\
\text { latrine }\end{array}$ & $\begin{array}{l}14 \% \text { greater } \\
\text { latrine use for } \\
\text { men in treatment }\end{array}$ & Not reported & Not reported \\
\hline
\end{tabular}

\footnotetext{
${ }^{8}$ It is worth noting, however, that these improvements have not led to corresponding increases in positive health outcomes or reduced incidence of disease. Patil and others (2014) found that increased availability of household latrines were insufficient to improve child health outcomes. ${ }^{9}$ Improved sanitation is defined as a sanitation facility 'that hygienically separates human excreta from human contact. Sanitation facilities shared with other households are not considered to be improved' (WHO and UNICEF 2015).
} 


\begin{tabular}{|c|c|c|c|c|}
\hline $\begin{array}{l}\text { Study and } \\
\text { intervention }\end{array}$ & $\begin{array}{l}\text { Latrine } \\
\text { coverage } \\
\text { difference }\end{array}$ & $\begin{array}{l}\text { Latrine use } \\
\text { difference }\end{array}$ & $\begin{array}{l}\text { Open defecation } \\
\text { rate } \\
\text { difference }\end{array}$ & $\begin{array}{l}\text { Child faeces } \\
\text { disposal } \\
\text { difference }\end{array}$ \\
\hline $\begin{array}{l}\text { Intensified } \\
\text { IEC } \\
\text { campaign }\end{array}$ & $\begin{array}{l}\text { coverage in } \\
\text { treatment } \\
\text { versus } \\
\text { control } \\
\text { villages }\end{array}$ & $\begin{array}{l}\text { versus control } \\
\text { villages } \\
\text { - } 14 \% \text { greater } \\
\text { latrine use for } \\
\text { women in } \\
\text { treatment versus } \\
\text { control villages } \\
6.5 \% \text { greater } \\
\text { latrine use for } \\
\text { children in } \\
\text { treatment versus } \\
\text { control villages }\end{array}$ & & \\
\hline $\begin{array}{l}\text { Clasen et al. } \\
2014^{10} \\
\text { India's Total } \\
\text { Sanitation } \\
\text { Campaign }\end{array}$ & $\begin{array}{l}51 \\
\text { percentage } \\
\text { points } \\
\text { greater } \\
\text { household } \\
\text { latrine } \\
\text { coverage in } \\
\text { intervention } \\
\text { versus } \\
\text { control } \\
\text { villages }\end{array}$ & $\begin{array}{l}27 \text { percentage points } \\
\text { greater household } \\
\text { latrine use in } \\
\text { treatment versus } \\
\text { control villages }\end{array}$ & Not reported & Not reported \\
\hline
\end{tabular}

\subsection{Total Sanitation Campaign}

Four studies included in this review examine latrine use in the context of the government's Total Sanitation Campaign, which was implemented from 1999 to 2012 (Dickinson 2008; Pattanayak et al. 2009; Clasen et al. 2014; Patil et al. 2014).

The Total Sanitation Campaign placed a strong emphasis on IEC for effective behaviour change. It required the involvement of panchayats (village councils), community-based organisations, and non-governmental organisations. Key components of the approach included activities to generate demand, elicit greater community involvement and encourage use of latrines. Key intervention areas included providing individual household latrines, school sanitation and hygiene education, community sanitary complexes (where there is no room for individual household latrines), toilets in anganwadi (child care centres), and toilets at rural sanitary marts and production centres. The Total Sanitation Campaign also provided low-level subsidies aimed at generating household involvement and stimulating demand for individual household latrines in below-poverty line households (Government of India 2012).

Our review revealed that despite its national scale, implementation of the Total Sanitation Campaign varied across states, partly in response to the socioeconomic context of each state. Barnard and others (2013) assessed the impact of the campaign

${ }^{10}$ No p-values available. 
on latrine use and coverage in rural Odisha three years after implementation. In Odisha, latrine coverage was 72 per cent in villages where Total Sanitation Campaign had been implemented, compared with less than 10 per cent in similar villages without Total Sanitation Campaign interventions. However, fewer than half of all households (47 per cent) reported that they used latrines at all times for defecation. In fact, a majority of the community still defecated in the open. Thus, increases in coverage were not met with equal gains in latrine use.

Similarly, Majorin and others (2014) assess the impact of the Total Sanitation Campaign on safe disposal of child faeces for children under five in rural Odisha three years after implementation. They find that a majority of pre-ambulatory children (57.5\%) defecated on the ground inside the household and that a majority of ambulatory children (55.2\%) defecated on the ground around the residential compound. Although the study mainly sampled households with latrines (78.6\%), less than one-quarter (22.8\%) used them for safe disposal of child faeces.

Coffey and others (2014), in contrast, did not explicitly seek to evaluate the impact of the Total Sanitation Campaign, nor its successor Nirmal Bharat Abhiyaan, but assess the degree to which rural respondents in Bihar, Madhya Pradesh, Rajasthan, Uttar Pradesh and Haryana receive monetary or material support from the government to build latrines. A majority of respondents (78.8\%) did not receive money or materials to build latrines from the government. Of these, 32 per cent built a latrine using their own means; the rest did not own a latrine. Amongst households with latrines, household members whose latrines were constructed with government support were more than twice as likely to defecate in the open than those who had built latrines without government support.

Coffey and others (2014) also explore the reach of government sanitation promotion messaging on beneficiaries. The majority of respondents (61 per cent) had heard of a government scheme providing assistance in constructing toilets, but only 31 per cent reported engaging with promotional materials such as posters, wall paintings, pamphlets, plays or films about using latrines. This indicates that IEC channels are likely not the main pathway through which households are stimulated to demand toilets. Additionally, the authors used a demographic model to illustrate the case that even if universal latrine coverage were achieved with government support, the majority of their sample would still defecate in the open, as sanitation preferences would remain unchanged.

\subsection{Barriers to latrine use}

The most frequently cited barriers to latrine use, as suggested by the included studies, are knowledge, attitudes and practices related to latrine use; poor latrine quality; and financial barriers. In this section, we discuss different barriers to latrine use, which are also summarised in Table 7.

\subsubsection{Knowledge, attitudes and practices}

Several studies examine knowledge, attitudes and practices related to latrine use. Barnard and others (2013) report that amongst the reasons given for not using a latrine, 29 per cent of the sample in rural Odisha preferred open defecation over latrine use and 20 per cent felt using a latrine was inconvenient. Coffey and others (2014) find that 81.6 per cent of rural residents in five northern Indian states defecate openly. Almost half 
(47\%) reported it to be more pleasurable than using a latrine. Nearly three-quarters of those who owned a latrine cited the same reason for open defecation. Barnard and others (2013) find that possessing knowledge of the benefits of latrine use is not correlated with an individual using a latrine. Clearly, knowledge of benefits is not sufficient to change behaviour.

\subsubsection{Poor latrine quality}

Poor construction can be another barrier to ensuring latrine use. Banda and others (2007) find that a major reason for the underuse of public latrines amongst rural populations in Tamil Nadu was that none of them had covered pits or were connected to septic tanks. Latrines were also reported to have foul odours in general and stagnant water during the monsoon, which some respondents reported as a major barrier to use.

Among their sample, Barnard and others (2013) find that 45 per cent believed their government-constructed latrines were incomplete or broken. Nearly all functional latrines (95 per cent) were used, compared with only one-third of non-functional latrines.

Poor quality of the latrine can have negative psychosocial consequences as well. Hirve and others (2015) find that amongst 127 adolescent school girls in rural Maharashtra, 21 per cent reported psychosocial stress due to the uncleanliness of available toilets. Amongst 278 household latrine users, 10 per cent reported inadequate lighting as a stressor for latrine use.

\subsubsection{Financial barriers}

Banda and others (2007) report that financial barriers can be a critical limitation for the construction of latrines. In a rural sample in Tamil Nadu, respondents claimed that they did not have funds to build toilets. Open defecation eliminated the need to maintain toilets. In the study area, although government-constructed public toilets were available for women, they were not used because of the monthly fee and the occasional reported lack of water. As a result, these public toilets were used mainly for bathing and washing clothes and rarely for defecation.

Coffey and others (2014) probed respondents' perceptions of latrine construction costs, finding that 78 per cent of male respondents who did not have a latrine reported cost of the latrine as an important reason for open defecation. Respondents reported that latrines cost, on average, 21,000 rupees (far more than the 10,000 rupees allotted by Government of India for construction). In contrast, O'Reilly and others (2015) find that adequate financial resources were not a barrier to latrine use in West Bengal. Though subsidies for poor households in this area were necessary for the initial construction, latrines remained in use for decades afterwards.

\subsubsection{Water supply}

Water supply does not appear to be an important correlate of latrine use, based on the included quantitative studies. Hirve and others (2015) sampled 306 women in a rural Maharashtrian community, finding that only 14 per cent of respondents felt that inadequate water was a major stressor for latrine use. Similarly, Coffey and others (2014) do not find water supply to be a major barrier to latrine use in a study of rural communities across Bihar, Haryana, Madhya Pradesh, Rajasthan and Uttar Pradesh. In 
their study, less than 1 per cent of men and 5 per cent of women who defecated in the open reported lack of water as constraint to latrine use.

Similarly, one study (Banda et al. 2007) finds no significant difference in self-reported toilet use amongst residents of a lower-caste colony, compared with a higher-caste colony, despite a significant difference in perceived adequate water availability.

Table 7: Barriers to latrine use examined in the included studies

\begin{tabular}{|l|l|l|l|l|l|c|}
\hline \multirow{2}{*}{ Study } & \multicolumn{5}{|c|}{ Barriers to latrine use } \\
\cline { 2 - 8 } & $\begin{array}{l}\text { Water } \\
\text { supply }\end{array}$ & $\begin{array}{l}\text { Foul } \\
\text { odours }\end{array}$ & $\begin{array}{l}\text { Poor } \\
\text { quality } \\
\text { of latrine }\end{array}$ & Financial & $\begin{array}{l}\text { Knowledge, } \\
\text { attitudes and } \\
\text { practices }\end{array}$ & Access \\
\hline Banda et al. (2007) & & & & & & \\
\hline Barnard et al. (2013) & & & & & & \\
\hline Coffey et al. (2014) & & & & & & \\
\hline Hirve et al. (2015) & & & & & & \\
\hline O'Reilly et al. 2015 & & & & $\mathbf{3}$ & $\mathbf{4}$ & $\mathbf{1}$ \\
\hline TOTAL & $\mathbf{3}$ & $\mathbf{2}$ & $\mathbf{3}$ & $\mathbf{3}$ & & \\
\hline
\end{tabular}

Not a barrier to latrine use

Barrier to latrine use

Not reported

\subsubsection{Gender, age and socioeconomic status}

The included studies suggest heterogeneous effects on the coverage and use of latrines with regard to gender, age, socioeconomic status, caste or tribe.

\section{Gender}

Nine of the 11 included studies (82 per cent) examine associations between gendered social norms and latrine use (Dickinson, 2008; Patil et al. 2014; Pattanayak et al. 2009; Coffey et al. 2014; Zacharia and Shordt, 2004; Banda et al. 2007; Barnard et al. 2013; Hirve et al. 2015; Clasen et al. 2014). Three studies carried out in Odisha and Madhya Pradesh find that men's and women's latrine use improved as a result of the Total Sanitation Campaign (Dickinson 2008; Patil et al. 2014; Pattanayak et al. 2009). Patil and others (2014) report that open defecation was generally similar for men and women, suggesting that gendered social norms do not exert a significant influence on reporting open defecation, which is usually prone to social desirability bias.

Women's safety did not appear to be a major concern in households in the sample of Pattanayak and others (2009), as only about 5-6 per cent of households in treatment and control groups expressed concern over women's safety during open defecation.

Four studies conducted in Kerala, Maharashtra, Odisha, Bihar, Haryana, Madhya Pradesh, Rajasthan and Uttar Pradesh note that women are more likely to use latrines than men (Coffey et al. 2014; Dickinson 2008; Zacharia and Shordt 2004; Clasen et al. 2014). This may be attributed to a preference for using latrines amongst women or to cultural norms that require women to stay home (Coffey et al. 2014).

However, the included studies do not demonstrate clear evidence to elucidate the causal mechanisms behind differential gendered effects of latrine use. This revealed preference may reflect gendered social norms in which latrine use is associated with women. This is reflected in a follow-up survey by Zacharia and Shordt (2004), in which participants who attended hygiene promotion classes demonstrated a tendency to recall that the classes 
were associated with women's latrine use, even though the intention was to promote hygiene and sanitation for the entire community.

\section{Age}

Five studies examine the use of latrines by children (Dickinson 2008; Pattanayak et al. 2009; Majorin et al. 2014; Clasen et al. 2014; Banda et al. 2007). Although one study in Odisha reports an equal proportion of children and adult males using the latrines (Clasen et al. 2014), most studies report that children have a higher incidence of open defecation than adults (Banda et al. 2007; Dickinson 2008), which decreases quickly during the teen years for females who have access to latrines (Coffey et al. 2014). Dickinson's (2008) study in Odisha reported that, amongst households owning a latrine, children's latrine use declined post-treatment (from 52 per cent in 2005 to 33 per cent in 2006), suggesting that children were not uniformly using the newly constructed latrines. Even amongst households with latrines, most child faeces were disposed of unsafely (e.g. in the household waste disposal site), which the Joint Monitoring Program for Water Supply and Sanitation considers to be open defecation (Majorin et al. 2014). The included studies do not report findings related to the elderly or individuals with disabilities.

\section{Socioeconomic status}

Five studies (45 per cent) report latrine ownership by poverty status (Dickinson 2008; Patil et al. 2014; Banda et al. 2007; Zacharia and Shordt 2004; Clasen et al. 2014). Not surprisingly, latrine ownership and latrine use were both higher amongst individuals with high socioeconomic status at baseline (Banda et al. 2007; Zacharia and Shordt 2004; Clasen et al. 2014). However, one study in Odisha reports that although latrine construction subsidies were only available for households below the poverty line, those above the poverty line were just as likely to adopt latrines (Dickinson 2008). The study attributes this phenomenon to increased availability of sanitation materials in the villages and to social effects. However, there is evidence to suggest that the Total Sanitation Campaign improved sanitation facilities amongst below poverty line households by 30 per centage points (Patil et al. 2014). Dickinson (2008) finds no correlation between wealth measures (e.g. expenditure on food and non-food items in the past 30 days) and ownership of consumer durables (e.g. televisions and mattresses) on latrine adoption. There is a significant positive correlation $(0.093 ; p<0.01)$ between living in a house with mud or thatch walls and latrine adoption.

\subsection{Risk of bias assessment for randomised controlled trials}

We performed a risk of bias assessment for studies that used RCTs (Dickinson 2008; Clasen et al. 2014; Pattanayak et al. 2009; Patil et al. 2014). Assessment criteria comprise the presence of the following risks: selection bias and confounding, spillovers and contamination, outcome reporting bias, analysis reporting bias, effect sizes bias and other sources of bias. Table 8 presents the results of the quality appraisal.

Three of the four studies describe the randomisation process; Patil and others (2014) and Pattanayak and others (2009) used public lottery and Clasen and others (2014) used a computer-generated sequence. These studies also report attrition rates and compare comparison and treatment groups. However, Pattanayak and others (2009) and Dickinson (2008) provide insufficient details on whether attrition rates were random or 
systematic. Patil and others (2014) present data on characteristics of the attrited and non-attrited samples but do not discuss issues with contamination of data.

In the study by Patil and others (2014), at least eight and possibly 10 control villages received the Total Sanitation Campaign intervention, but it is not clear that spillovers or contamination are controlled for in the analysis. On the other hand, Dickinson (2008) and Pattanayak and others (2009) group the study villages by panchayat, selected one village per panchayat and removed contiguous villages to reduce possible spillover effects. Clasen and others (2014) do not report how risks for selection bias, confounding, spillovers and contamination are mitigated.

All four studies address how they have mitigated biases in outcome and analyses. However, these studies are unlikely to be free of other sources of bias, including issues such as blinding outcome assessors or data analysts, courtesy bias from respondents in their self-reports and appropriateness of data collection instruments. Patil and others (2014) discuss these other sources of biases but do not actually control for them. Dickinson (2008) and Pattanayak and others (2009) address only the issue of blinding the data collection process. 
Table 8: Risk of bias assessment for RCTs

\begin{tabular}{|c|c|c|c|c|c|c|c|c|}
\hline Study & $\begin{array}{l}\text { Study design } \\
\text { (analysis } \\
\text { method) }\end{array}$ & $\begin{array}{l}\text { Selection bias and } \\
\text { confounding } \\
\text { addressed }\end{array}$ & $\begin{array}{l}\text { Spillovers and } \\
\text { contamination } \\
\text { addressed }\end{array}$ & $\begin{array}{l}\text { Outcome } \\
\text { reporting bias } \\
\text { addressed }\end{array}$ & $\begin{array}{l}\text { Analysis } \\
\text { reporting bias } \\
\text { addressed }\end{array}$ & $\begin{array}{l}\text { Effect sizes } \\
\text { addressed }\end{array}$ & $\begin{array}{l}\text { Other sources } \\
\text { of bias } \\
\text { addressed }\end{array}$ & $\begin{array}{l}\text { Overall risk of } \\
\text { bias } \\
\text { assessment }\end{array}$ \\
\hline Patil et al. (2014) & RCT (cluster) & & & & & & & High risk \\
\hline Pattanayak et al. (2009) & RCT (cluster) & & & & & & & High risk \\
\hline Dickinson (2008) & RCT (cluster) & & & & & & & High risk \\
\hline Clasen et al. (2014) & RCT (cluster) & & & & & & & Medium risk \\
\hline
\end{tabular}

\section{Legend:}

\begin{tabular}{|l|l|}
\hline Yes & \\
\hline No & \\
\hline Unclear & \\
\hline
\end{tabular}




\subsection{Results of stakeholder consultations and field trip}

The most important barriers to latrine use identified by stakeholders were the need for behaviour change in the local administration and amongst users, beliefs about purity and pollution, the lack of priority given to toilet construction by rural residents, the poor quality of toilets and social norms. Medium importance was given to gender relations, implementation obstacles, insufficient water in proximity to the latrine, the need to target shame and a subsidy or incentive-driven approach. Similarly, the cost-effectiveness of different latrine options presented through sanitation marketing and improvements in the supply chain were highlighted as other areas sorely in need of evidence. Access to water for latrines and psychosocial stress engendered by subsidies and microcredit loans was also cited for lack of evidence.

The field visit to rural Rajasthan confirmed several of the findings in the literature. Discussions with a Swachh Bharat Mission coordinator in the area revealed that local officials were facing immense pressure to meet construction targets. Additionally, in the coordinator's opinion, behaviour change work with non-governmental and multilateral organisations had resulted in work which did not reflect the 'ground realities'. For instance, the design of certain latrines seen in the field appeared difficult to use for women and increased their household burdens, due to the amount of water required for latrine use and maintenance. The major takeaway from the village sites was the substantial heterogeneity in village characteristics, even with the same panchayat. The scalability of any sanitation intervention would need to carefully consider contextual factors facilitating or hindering successful implementation.

\section{Discussion}

This section discusses the findings and presents recommendations for future research efforts. Key knowledge gaps are presented first, followed by quality of the evidence, supply and demand factors influencing latrine use, issues with latrine use measurement and limitations.

\subsection{Gaps in the evidence}

Our study shows that there is limited rigorous quantitative literature that examines latrine use. We found only 11 studies that met our criteria, and only four that measure attributable change in latrine use as a result of an intervention. This finding is unsurprising. Most literature on individual outcomes in the sanitation sector carry a strong focus on health indicators, such as diarrhoea, helminthiases or malnutrition. Pattanayak and others (2009) and Dickinson (2008) use the same sample population, as do Clasen and others (2014), Barnard and others (2013) and Majorin and others (2014), with a different sample. The shared datasets amongst multiple studies further highlights the lack of diversity in published data. None of the studies included in this review present interventions to affect latrine use, seeking instead to assess the effectiveness of national sanitation programs.

Additionally, none of the included studies reports the use of a theory-based approach to behaviour change. The few causal studies related to latrine use underscore the inherent difficulties in measuring latrine use and the multitude of influences within an environment 
that affect an individual's decision to use a latrine. Although four of the included studies measure causal attribution of government programs on latrine use outcomes, these studies do not investigate implementation fidelity. It is therefore difficult to infer if the intervention design or implementation is a key barrier for effectiveness.

\subsection{Addressing risk of bias}

Addressing potential sources of bias will increase confidence in the validity of results. We assessed the four RCTs for risk of bias, summarised by an overall assessment of low, medium or high risk with respect to selection bias, spillovers, contamination and other sources of bias. This suggests a few areas of improvement for further impact evaluation studies on latrine use in rural India.

There is a need to properly justify the choice of the study area. This choice does not need to result from a random process, but clear insights on the selection criteria will help inform the extent to which results can be generalised. Given the heterogeneity of rural Indian populations, a clear, careful definition or delimitation of who is eligible (in geographical, social and institutional units) is required. In addition to spillovers and contamination, studies need to consider other sources of bias, such as blinding of data analysts, courtesy behaviour of respondents in self-reporting and appropriateness of data collection instruments. These issues are important for reflecting actual latrine use.

Unlike other outcome variables that are more straightforward to measure and monitor (e.g. income, body mass index and school attendance rate), latrine use could be tricky to assess due to social norms and irregular use. As a result, there is a higher risk of overor under-reporting, with implications for impact estimates. A clear description of how different sources of bias are addressed or considered will increase confidence in the validity of results.

\subsection{Supply-driven determinants of latrine use}

Latrine design and functionality influence use, and building a latrine without due consideration of these factors can result in non-use or repurposing of the latrine. Amongst studies included in this review, as well as those conducted elsewhere (i.e. not in rural India), user acceptability of the latrine design (including location) is a prime motivating factor in latrine use that may differentially affect one's willingness to pay for different options. In this regard, future research efforts might seek to evaluate the effects of sanitation marketing on willingness to construct and use a latrine. This is especially relevant to India, given that the government has made production centres and rural sanitation marts available in some rural areas (World Bank 2013). These facilities were established with the intention of making a variety of sanitary options affordable for the rural consumer.

User-centred designs also carry the potential for making latrines more accessible to those with unique needs. A handrail, for instance, could benefit those requiring extra support, such as elderly people, pregnant women and children. A proliferation of alternative latrine options and pricing structures could address the financial barriers reported by Banda and others (2007) and Coffey and others (2014). The design of the latrine is particularly relevant to attitudes towards latrine use given findings from Coffey 
and others (2014) and Barnard and others (2013), suggesting that the perceived convenience of open defecation remains a key barrier to latrine use.

\subsection{Demand-driven approaches to latrine use}

The habitual nature of most behaviour represents an understudied aspect of previous sanitation interventions and a target for future interventions. Certain knowledge, attitudes and practices appear to inhibit latrine use. The perceived convenience and pleasant nature of open defecation is reported in some of the included studies. ${ }^{11}$ When one considers the additional costs associated with cleaning and maintenance of the latrine, it is perhaps unsurprising why households discount the public health benefits, which can be less salient than the immediate cost. Findings from the public health literature indicate that campaigns focused on providing information on the negative consequences or benefits of a particular decision (e.g. to smoke or not to smoke) have modest or no effects on reducing health-harming behaviours (Marteau et al. 2012). Such campaigns target the individual's reflective, deliberative decision-making system, whereas most behaviour in daily life is automatic, conducted without conscious deliberation (Marteau et al. 2012; World Bank 2014). Thus, whether the psychosocial antecedents of latrine use behaviour involve the perceived convenience of open defecation or the tacit acceptance of social norms regarding who can use a latrine, the automatic system of individual decision-making represents fertile ground for future research efforts.

Using theory in designing behaviour change interventions can provide a framework for testing the relationship between different intervention components, hypothesised mediators and outcomes. There is a paucity of theory-driven behaviour change interventions to promote latrine use in rural India. Most demand-driven approaches to latrine use from the included studies come from national sanitation programmes, which typically involve community mobilisation and triggering (including CLTS), provision of subsidies to beneficiaries and IEC campaigns. Given the evidence on latrine non-use despite latrine ownership, latrine use appears to be an understudied construct that merits attention. A recent systematic review by De Buck and others (2017) is a step in this direction, examining the elements of sanitation and handwashing interventions, including the use of psychosocial theory in both.

Comparisons of different financial and non-financial incentives to promote latrine use are a notable omission in the behaviour change literature. Incentives can be incorporated into theory-driven behaviour change interventions. We enumerate two possible reasons, with the caveat that these need to be investigated rigorously:

- Many beneficiaries perceive the 12,000 rupee incentive from the government to be inadequate for latrine construction; and

- Latrines constructed with that incentive are less likely to be used than those constructed privately, due to poor quality of infrastructure.

Incentives and subsidies do not affect behaviour in symmetric ways: Incentives provide a 'bonus' to individuals with latrines, which can take different forms, such as social

\footnotetext{
${ }^{11}$ This point is perhaps best summarised by a water, sanitation and hygiene programme manager we consulted in India, whose assessment was that, 'Our greatest enemy in encouraging latrine use is fresh air'.
} 
recognition and prizes. Although the systematic search identified some studies describing the results of the Nirmal Gram Puraskar (Clean Village Award), none met our inclusion criterion of studies reporting the results of statistical analyses on latrine use. A study commissioned by the Government of India (2011) on the Nirmal Gram Puraskar is one example that did not meet our inclusion criteria for a quantitative study, but attempts to study the effect of the incentive.

Our systematic search of the literature did not reveal any studies examining the effectiveness of nonmonetary incentives to promote latrine use. A study on intrinsic motivational factors can help elucidate which nonmonetary incentives might be incorporated in an intervention. For instance, appealing to an individual's desire for status or recognition might be incorporated through a public recognition of achieving the target behaviour. The World Bank (2013) describes a campaign in the Churu district of Rajasthan in which the phrase 'clean and beautiful house' was painted on houses whose occupants had ceased open defecation. Although this case study does not present rigorous quantitative evidence, the appeal to intrinsic motivational factors merits further exploration.

Additionally, no included studies examined rural Indians' willingness to pay for latrines or the effectiveness of pay-for-use mechanisms. This is surprising given the 'missing middle' rung of the sanitation ladder in rural India, which highlights a significant per centage of the population in rural India who consider sanitation options very limited (Coffey et al. 2014).

\subsection{Measurement challenges}

Measuring latrine use with a reasonable degree of accuracy requires triangulating methods and data. This requires substantial investments of funds and time. No measurement method perfectly captures actual latrine usage, and all measurement indices in this domain are prone to errors of sensitivity and accuracy. Though monitoring devices such as PLUMs are gaining ground in the literature, they also have limitations, such as the inability to differentiate between distinct users within a few minutes of each other, hardware failure and difficulties distinguishing between defecation and behaviours such as urination, disposal of child faeces, latrine cleaning or menstrual hygiene.

Perhaps the most common method for assessing latrine use, certainly amongst the included studies, is to solicit information on use from individuals using self-reporting questionnaires. The danger of Hawthorne effects, or social desirability bias, is inherent in this methodology. The included study by O'Reilly and others (2015) is notable, in that it finds a statistically significant difference between latrine use data captured by PLUMs and by ethnography. PLUMs show higher usage than self-reports, likely because PLUMs cannot detect whether individuals are using latrine for defecation or other purposes, such as urination or accessing stored water.

This result contrasts with Sinha and others (2016), who find that self-reported daily latrine use is 118 per cent higher, on average, than PLUM-recorded latrine use. However, the authors in this study find that when comparing 48-hour recall with PLUMrecorded events for the same period, the discrepancy is far less. The correlation between PLUMs and self-reports for the previous 48 hours indicates moderate 
agreement between both measures. ${ }^{12}$ It is also significantly more concordant than the condition in which participants report average daily use. This suggests that asking individuals about their defecation habits yesterday and the day before yesterday might be a more accurate method than asking about average daily use, since it reduces recall bias.

A little more than half of the included studies (six of the 11) assess latrine use with selfreporting alone. Although measuring latrine use through self-reporting carries a number of biases, such as social desirability and Hawthorne effects, the way the questions are formulated and asked can yield significantly different answers. Indeed, it is important to consider the period for which individuals are being asked to recall behaviour. We conclude that self-reporting is often the most feasible option, but should be combined with some other observational method, if possible.

Disaggregated data to account for different household members' latrine use is not commonly reported in the included studies and remains a limitation in the data. While it may be more expedient to collect data for aggregated household latrine use, this does not help understand individual use patterns and is ultimately not useful if the target of the intervention is to achieve a community free of open defecation. Additionally, collecting data on individual use requires enumerators to be mindful of a number of factors, such as how they are perceived by the target population, the manner in which they solicit information and the intra-household dynamics which can affect responses. Future studies should seek to elicit responses for latrine use from all household members as a preliminary step towards understanding latrine use from specific perspectives, such as marginalised or vulnerable groups. However, disaggregation alone is insufficient to understand these perspectives.

In this regard, the Safe San Index appears promising for measuring a household's safe sanitary disposal of excreta, accounting for household members' differential usage patterns (Jenkins et al. 2014). In this study, the reliability of household members' answers was tested by comparing responses about household defecation practices from two visits, four weeks apart. Further, the authors have constructed an index to measure the individual respondents' propensity to give socially desirable responses. When piloted, they find no correlation between an individual's propensity to give socially desirable responses and reported latrine use, suggesting that the Safe San Index elicits socially unbiased responses through its use of multiple items and closed-ended formulations.

An additional approach concerns measuring the determinants of latrine use as a proxy for latrine use. One approach employed by Dreibelbis and others (2015) is the development and use of two attitudinal indices, comprising questions related to feelings related to open defecation, injunctive norms (what one should do in a given situation according to informal rules, morality or injunctions), descriptive norms (social empirical expectations of what others do), access and sharing of a latrine, attitudes towards specific latrine technologies, and perceptions of convenience in using a latrine. There are strong interactions between scales and a clear relationship with behavioural outcomes,

\footnotetext{
${ }^{12}$ Assessed by the concordance correlation coefficient, which is a standardised measure of the variation between methods.
} 
suggesting that such proxy measures for use merit consideration in future studies measuring latrine use.

\section{Conclusion}

The objective of this scoping paper is to examine the quantitative evidence of latrine use in rural India and inform 3ie's thematic window on the subject. Given this objective, we have identified six characteristics of the available evidence:

1. The lack of quantitative evidence;

2. The importance of design and functionality for latrine use;

3. The importance of triangulating measures of latrine use;

4. How sources of bias are addressed;

5. The lack of theory-driven behaviour change approaches to promoting latrine use; and

6. The lack of evidence on the effectiveness of monetary and nonmonetary incentives.

Based on the included studies, the existing evidence is not very rigorous. We found only four experimental studies and no quasi-experimental studies or systematic reviews. Most of the literature appears to report the results of various socioeconomic surveys of latrine use, with few studies focusing on a specific intervention. Additionally, the lack of psychosocial theory used to develop an intervention to increase latrine use is a major limitation in the literature. Given the historical entrenchment of open defecation, social norms (particularly gendered social norms) and automatic natural habits and latrine use behaviour should be addressed with greater theoretical rigour. This would allow for a testable empirical framework with which researchers can understand the relative contributions of factors influencing an individual's decision to use a latrine.

The major barriers to use appear to be poor latrine quality and certain inhibiting knowledge, attitudes and practices (e.g. perceived convenience and pleasure of open defecation, despite knowing the health consequences). The importance of the design and location of the latrine appear to carry significant implications for use. The results from the consultative workshops echo those of the quantitative literature, in that knowledge, attitudes and practices (especially related to purity and pollution) and poor quality of infrastructure are major barriers to latrine use. Similarly, the field visit showed that latrine design is a major determinant of use.

More research is needed on methods to inform and engage individuals in the design process for their latrines and create a sense of ownership. Changing mindsets is a much harder process, although it can be addressed through using psychosocial theory to design interventions.

This scoping paper represents a preliminary step towards understanding the state of evidence on latrine use in rural India. It identifies the major barriers and determinants of latrine use and provides recommendations for introducing greater theoretical and statistical rigour into future research to promote latrine use. 


\section{Appendix A: Methods}

\section{Inclusion and exclusion criteria}

Table A1 outlines the full inclusion and exclusion criteria using population, intervention, comparator, outcome and study design.

Table A1: Inclusion and exclusion criteria

\begin{tabular}{|c|c|c|}
\hline \multicolumn{2}{|r|}{ Include } & \multirow{2}{*}{$\begin{array}{l}\text { Exclude } \\
\text { - Urban Indian } \\
\text { populations } \\
\text { - Any population } \\
\text { outside rural India }\end{array}$} \\
\hline Population & $\begin{array}{l}\text { Rural Indian individuals, households, } \\
\text { communities, and/or villages } \\
\text { - Studies which include a rural Indian population. }\end{array}$ & \\
\hline Intervention & $\begin{array}{l}\text { Interventions for increasing latrine use: } \\
\text { - Behaviour change } \\
\text { o Examples include CLTS, information providing } \\
\text { intervention including one-on-one interactive } \\
\text { sessions on latrine benefits, mass media } \\
\text { campaigns, and information, IEC activities } \\
\text { including interviews with stakeholders } \\
\text { - Infrastructure } \\
\text { o Examples include construction of latrines, } \\
\text { subsidies for latrine construction, improving } \\
\text { water supply in latrines, production centres to } \\
\text { design and construct locally appropriate } \\
\text { latrines, fly control interventions, human } \\
\text { excreta disposal interventions, Total } \\
\text { Sanitation Campaign } \\
\text { Combination of behavioural and infrastructural } \\
\text { interventions }\end{array}$ & $\begin{array}{l}\text { - Interventions } \\
\text { unrelated to latrine } \\
\text { use }\end{array}$ \\
\hline Comparator & $\begin{array}{l}\text { Quantitative studies which compare a treatment } \\
\text { with an alternative treatment or no treatment, or } \\
\text { did not have comparison groups. }\end{array}$ & \\
\hline Outcomes & $\begin{array}{l}\text { Latrine use (as either primary, secondary or } \\
\text { tertiary outcome) } \\
\text { - Knowledge, attitudes and beliefs regarding latrine } \\
\text { use } \\
\text { - Infrastructural improvements (e.g. financing, } \\
\text { latrine construction) related to latrine use } \\
\text { - Policy changes to promote increased latrine use }\end{array}$ & $\begin{array}{l}\text { - Anthropometric } \\
\text { measures } \\
\text { - Health outcomes } \\
\text { - } \text { Open defecation rate } \\
\text { not related to latrine } \\
\text { use }\end{array}$ \\
\hline
\end{tabular}




\begin{tabular}{|c|c|c|}
\hline & Include & Exclude \\
\hline Study design & $\begin{array}{l}\text { - Experimental: RCTs (cluster and individual } \\
\text { assignment) } \\
\text { - Quasi-experimental: propensity score matching, } \\
\text { regression discontinuity, difference-in-difference } \\
\text { with matching, difference-in-difference without } \\
\text { matching, instrumental variables, single difference } \\
\text { and others (fixed effects and random effects), } \\
\text { interrupted times series, natural experiments } \\
\text { - } \text { Mixed-method studies (involving quantitative and } \\
\text { qualitative data analyses) } \\
\text { - Non-experimental: (case-control, cross-sectional, } \\
\text { longitudinal, cohort, ecological, case-studies) } \\
\text { - Systematic reviews: any study that had systematic } \\
\text { review in the published title }\end{array}$ & $\begin{array}{l}\text { - Purely qualitative } \\
\text { studies }\end{array}$ \\
\hline
\end{tabular}

\section{Complete search strategy for one database}

Database: Ovid MEDLINE(R) In-Process \& Other Non-Indexed Citations, Ovid MEDLINE(R) Daily and Ovid MEDLINE(R) $<1946$ to Present $>$ Searched $16^{\text {th }}$ March 2016

1 (india or "andhra pradesh" or "arunachal pradesh" or assam or bihar or Chhattisgarh or goa or gujarat or haryana or "himachal pradesh" or jammu or kashmir or Jharkhand or karnataka or kerala or "madhya pradesh" or maharashtra or manipur or meghalaya or mizoram or nagaland or odisha or orissa or punjab or rajasthan or sikkim or "tamil nadu" or telangana or tripura or "uttar pradesh" or uttarakhand or "west bengal" or andaman or nicobar or chandigarh or dadra or "nagar haveli" or daman or diu or lakshadweep or delhi or "national capital territory" or puducherry or pondicherry or (gram adj2 india) or panchayat* or "swachh bharat" or "nirmal bharat").ti,ab,sh. (114071)

2 exp India/ (81953)

31 or $2(114071)$

4 (latrine* or lavator* or (wc not (cancer* or carcinoma or neoplasm*)) or "water closet $^{\star *}$ or toilet* or ((open or outside or outdoors) adj3 (defecat* ${ }^{\star}$ or defaecat ${ }^{\star}$ or excret*))).ti,ab. (11120)

5 Toilet Facilities/ (1231)

6 Defecation/ (6091)

74 or 5 or $6(17629)$

83 and 7 (367)

9 limit 8 to $y r=" 1996$-Current" (299) 


\section{Appendix B: Complete list of variables extracted from included studies}

\begin{tabular}{|c|c|c|c|c|c|c|c|}
\hline Study & Overall objective & Study design & $\begin{array}{l}\text { Coverage } \\
\text { (Number of } \\
\text { villages) }\end{array}$ & $\begin{array}{l}\text { Primary unit(s) } \\
\text { of analysis and } \\
\text { (sample size) }\end{array}$ & $\begin{array}{l}\text { Selection of main } \\
\text { units }\end{array}$ & $\begin{array}{l}\text { Data collection } \\
\text { methods }\end{array}$ & $\begin{array}{l}\text { Quantitative } \\
\text { analytical methods }\end{array}$ \\
\hline $\begin{array}{l}\text { Banda et } \\
\text { al. } 2007\end{array}$ & $\begin{array}{l}\text { Understand sociocultural } \\
\text { factors that influence water } \\
\text { usage and safety in rural Tamil } \\
\text { Nadu }\end{array}$ & $\begin{array}{l}\text { Cross } \\
\text { sectional and } \\
\text { mixed- } \\
\text { methods }\end{array}$ & 1 & $\begin{array}{l}\text { Households (179 } \\
\text { HHs) } \\
\text { Individuals } \\
\text { (179 Ids) }\end{array}$ & Purposive & $\begin{array}{l}\text { - Semi-structured } \\
\text { questionnaires } \\
\text { - Focus groups }\end{array}$ & $\begin{array}{l}\text { - Descriptive } \\
\text { statistics } \\
\text { - Comparison tests }\end{array}$ \\
\hline $\begin{array}{l}\text { Barnard et } \\
\text { al. } 2013\end{array}$ & $\begin{array}{l}\text { Investigate latrine coverage and } \\
\text { use in Orissa }\end{array}$ & $\begin{array}{l}\text { Cross } \\
\text { sectional }\end{array}$ & 30 & $\begin{array}{l}\text { HHs (447) } \\
\text { Ids }(1,933)\end{array}$ & Purposive & $\begin{array}{l}\text { - Surveys } \\
\text { - Spot checks of } \\
\text { latrines }\end{array}$ & $\begin{array}{l}\text { - Descriptive } \\
\text { statistics } \\
\text { - Chi-square tests } \\
\text { - Logistic regression }\end{array}$ \\
\hline $\begin{array}{l}\text { Clasen et } \\
\text { al. } 2014\end{array}$ & $\begin{array}{l}\text { Assess effectiveness of a rural } \\
\text { sanitation intervention in the } \\
\text { context of the Government of } \\
\text { India's Total Sanitation } \\
\text { Campaign to prevent diarrhoea, } \\
\text { soil-transmitted helminth } \\
\text { infection, and } \\
\text { child malnutrition }\end{array}$ & $\begin{array}{l}\text { RCT } \\
\text { (randomised } \\
\text { village-level) }\end{array}$ & 100 & $\begin{array}{l}\text { HHs }(2,902) \\
\text { Ids }(20,283)\end{array}$ & $\begin{array}{l}\text { Enrolment based on } \\
\text { following criteria: } \\
\text { household has a } \\
\text { child under four } \\
\text { years of age, or a } \\
\text { pregnant woman. }\end{array}$ & $\begin{array}{l}\text { - Surveys } \\
\text { - Spot checks of } \\
\text { latrines } \\
\text { - GPS data } \\
\text { - Lab tests }\end{array}$ & $\begin{array}{l}\text { - } \text { Descriptive } \\
\text { statistics } \\
\text { - Ordered logistic } \\
\text { regression } \\
\text { - Negative binomial } \\
\text { regression }\end{array}$ \\
\hline $\begin{array}{l}\text { Coffey et } \\
\text { al. } 2014\end{array}$ & $\begin{array}{l}\text { Assess sanitation quality, use, } \\
\text { access, and trends }\end{array}$ & $\begin{array}{l}\text { Cross } \\
\text { sectional }\end{array}$ & Not reported & $\begin{array}{l}\text { HHs }(3,235) \\
\text { Ids }(22,787)\end{array}$ & Random & - Interviewers & $\begin{array}{l}\text { - Descriptive } \\
\text { statistics } \\
\text { - Logistic regression }\end{array}$ \\
\hline $\begin{array}{l}\text { Dickinson } \\
2008\end{array}$ & $\begin{array}{l}\text { Impact evaluation of a national } \\
\text { sanitation campaign in rural }\end{array}$ & $\begin{array}{l}\text { RCT } \\
\text { (randomised } \\
\text { community- } \\
\text { level) }\end{array}$ & $\begin{array}{l}40 \\
(20 \text { control } \\
\text { and } 20 \\
\text { treatment })\end{array}$ & $\mathrm{HHs}(1,050)$ & Random & $\begin{array}{l}\text { - Baseline in Aug } 2005 \\
\text { - Follow-up surveys in } \\
2006 \text { (Household } \\
\text { survey, Community } \\
\text { survey with key } \\
\text { informants, Water } \\
\text { quality, Informal } \\
\text { interviews with key } \\
\text { stakeholders) }\end{array}$ & $\begin{array}{l}\text { - Descriptive } \\
\text { Statistics } \\
\text { - Difference-in- } \\
\text { difference (DID) } \\
\text { estimate } \\
\text { - Probit regression } \\
\text { - IV model }\end{array}$ \\
\hline
\end{tabular}




\begin{tabular}{|c|c|c|c|c|c|c|c|}
\hline Study & Overall objective & Study design & $\begin{array}{l}\text { Coverage } \\
\text { (Number of } \\
\text { villages) }\end{array}$ & $\begin{array}{l}\text { Primary unit(s) } \\
\text { of analysis and } \\
\text { (sample size) }\end{array}$ & $\begin{array}{l}\text { Selection of main } \\
\text { units }\end{array}$ & $\begin{array}{l}\text { Data collection } \\
\text { methods }\end{array}$ & $\begin{array}{l}\text { Quantitative } \\
\text { analytical methods }\end{array}$ \\
\hline $\begin{array}{l}\text { Hirve et al. } \\
2015\end{array}$ & $\begin{array}{l}\text { Study of sources of } \\
\text { psychosocial stress related to } \\
\text { defecation practices among } \\
\text { women and adolescent girls }\end{array}$ & $\begin{array}{l}\text { Cross- } \\
\text { sectional with } \\
\text { mixed } \\
\text { methods }\end{array}$ & 22 & Women (308) & $\begin{array}{l}\text { Simple age stratified } \\
\text { random sample } \\
\text { generated } \\
\text { from the HDSS } \\
\text { database to achieve } \\
\text { an evaluable sample } \\
\text { size of } \\
150 \text { adolescent girls } \\
\text { (13-17 years) and } \\
150 \text { women } \\
\text { (18-35 years) }\end{array}$ & $\begin{array}{l}\text { - Survey questionnaire } \\
\text { - Community survey } \\
\text { - Focus group } \\
\text { discussion } \\
\text { - Key informant } \\
\text { interviews } \\
\text { - Free listing exercise }\end{array}$ & $\begin{array}{l}\text { - Descriptive } \\
\text { Statistics } \\
\text { - Student's t-test } \\
\text { - Chi-square test }\end{array}$ \\
\hline $\begin{array}{l}\text { Majorin et } \\
\text { al. } 2014\end{array}$ & $\begin{array}{l}\text { Assess the impact of the Total } \\
\text { Sanitation Campaign on child } \\
\text { faeces disposal practices }\end{array}$ & $\begin{array}{l}\text { Cross- } \\
\text { sectional }\end{array}$ & 20 & $\begin{array}{l}\text { HHs (136) } \\
\text { Children (136) }\end{array}$ & $\begin{array}{l}\text { Purposive and } \\
\text { random }\end{array}$ & $\begin{array}{l}\text { - Structured survey } \\
\text { - Spot checks of } \\
\text { household latrines }\end{array}$ & $\begin{array}{l}\text { - Univariate } \\
\text { - Descriptive } \\
\text { statistics } \\
\text { - Bivariate analysis } \\
\text { - Logistic regression }\end{array}$ \\
\hline $\begin{array}{l}\text { O'Reilly et } \\
\text { al. } 2015\end{array}$ & $\begin{array}{l}\text { Examines the sanitation } \\
\text { behaviour of individuals }\end{array}$ & $\begin{array}{l}\text { Cross- } \\
\text { sectional with } \\
\text { mixed- } \\
\text { methods }\end{array}$ & & HHs (258) & Purposive & $\begin{array}{l}\text { - Ethnographic } \\
\text { interviews } \\
\text { - observational } \\
\text { methods } \\
\text { - Sensor monitoring } \\
\text { with the Portland } \\
\text { State University } \\
\text { PLUMs }\end{array}$ & $\begin{array}{l}\text { - univariate } \\
\text { - descriptive } \\
\text { statistics }\end{array}$ \\
\hline $\begin{array}{l}\text { Patil et al. } \\
2014\end{array}$ & $\begin{array}{l}\text { Evaluate the Total Sanitation } \\
\text { Campaign and the various } \\
\text { components in the causal } \\
\text { pathways between reduction in } \\
\text { open defecation and improved } \\
\text { health outcomes }\end{array}$ & RCT & 80 & $\begin{array}{l}\text { HHs }(3,039) \\
\text { Children under } \\
\text { five }(5,209)\end{array}$ & Random & $\begin{array}{l}\text { - } \text { Baseline survey in } \\
\text { July } 2009 \\
\text { - Follow-up survey in } \\
\text { April } 2011 \\
\text { - } 16 \% \text { (treatment } \\
\text { group) and } 15 \% \\
\text { (control group) } \\
\text { attrition }\end{array}$ & $\begin{array}{l}\text { - Univariate } \\
\text { - Descriptive } \\
\text { statistics } \\
\text { - Linear regression } \\
\text { model of ITT }\end{array}$ \\
\hline
\end{tabular}




\begin{tabular}{|c|c|c|c|c|c|c|c|}
\hline Study & Overall objective & Study design & $\begin{array}{l}\text { Coverage } \\
\text { (Number of } \\
\text { villages) }\end{array}$ & $\begin{array}{l}\text { Primary unit(s) } \\
\text { of analysis and } \\
\text { (sample size) }\end{array}$ & $\begin{array}{l}\text { Selection of main } \\
\text { units }\end{array}$ & $\begin{array}{l}\text { Data collection } \\
\text { methods }\end{array}$ & $\begin{array}{l}\text { Quantitative } \\
\text { analytical methods }\end{array}$ \\
\hline $\begin{array}{l}\text { Pattanayak } \\
\text { et al. } 2009\end{array}$ & $\begin{array}{l}\text { Examine if labelling open } \\
\text { defecation as a shameful } \\
\text { practice is more effective than } \\
\text { subsidies in attempts to } \\
\text { increase latrine use }\end{array}$ & RCT & $\begin{array}{l}40(20 \\
\text { treatment and } \\
20 \text { control })\end{array}$ & $\mathrm{HHs}(1,050)$ & Random & $\begin{array}{l}\text { - } \text { Baseline in Sept. } \\
2005 \\
\text { - } \text { Follow-up in Sept. } \\
2006 \\
\text { - HH and community } \\
\text { survey instruments } \\
\text { - } 2.4 \% \text { (treatment } \\
\text { group) to } 4.2 \% \\
\text { (control group) } \\
\text { attrition }\end{array}$ & $\begin{array}{l}\text { - Univariate } \\
\text { descriptive models } \\
\text { (DID based) }\end{array}$ \\
\hline $\begin{array}{l}\text { Zacharia } \\
\text { and Shordt } \\
2004\end{array}$ & $\begin{array}{l}\text { Investigate whether a hygiene } \\
\text { intervention within community- } \\
\text { based sanitation and water } \\
\text { projects has an impact on } \\
\text { behaviours measured } 1 \text { to } 9 \\
\text { years after the projects have } \\
\text { ended }\end{array}$ & $\begin{array}{l}\text { Cross- } \\
\text { sectional }\end{array}$ & $\begin{array}{l}10 \\
\text { communities }\end{array}$ & $\mathrm{HHs}$ (345) & Random & $\begin{array}{l}\text { - } 2 \text { surveys (2001 and } \\
\text { - } 2002 \\
\text { - Questionnaire }\end{array}$ & $\begin{array}{l}\text { Descriptive } \\
\text { statistics } \\
\text { Econometric test } \\
\text { (not specify) }\end{array}$ \\
\hline
\end{tabular}




\section{Appendix C: List of included studies}

Banda, K, Sarkar, R, Gopal, S, Govindarajan, J, Harijan, BB, Jeyakumar, MB, Mitta, P, Sadanala, ME, Selwyn, T, Suresh, CR, Thomas, VA, Devadason, P, Kumar, R, Selvapandian, D, Kang, G and Balraj, V, 2007. Water handling, sanitation and defecation practices in rural southern India: A knowledge, attitudes and practices study.

Transactions of the Royal Society of Tropical Medicine and Hygiene, 101, pp.11241130.

Barnard, S, Routray, P, Majorin, F, Peletz, R, Boisson, S, Sinha, A and Clasen, T, 2013. Impact of Indian total sanitation campaign on latrine coverage and use: A cross-sectional study in Orissa three years following programme implementation. PLOS ONE, 8(8).

Clasen, T, Boisson, S, Routray, P, Torondel, B, Bell, M, Cumming, O, Ensink, J, Freeman, M, Jenkins, M, Odagiri, M, Ray, S, Sinha, A, Suar, M and Schmidt, WP, 2014. Effectiveness of a rural sanitation programme on diarrhoea, soil-transmitted helminth infection, and child malnutrition in Odisha, India: a cluster-randomised trial. The Lancet Global Health, 2, e645-e653.

Coffey, D, Gupta, A, Hathi, P, Khurana, N, Spears, D, Srivastav, N and Vyas, S, 2014. Revealed preference for open defecation. Economic and Political Weekly, 49, p.43.

Dickinson, KL, 2008. Indian toilets and Tanzanian mosquito nets: understanding households' environmental health decisions in developing countries. Dissertation Abstracts International Section A: Humanities and Social Sciences, 69, p.1078.

Hirve, S, Lele, P, Sundaram, N, Chavan, U, Weiss, M, Steinmann, P and Juvekar, S, 2015. Psychosocial stress associated with sanitation practices: Experiences of women in a rural community in India. Journal of Water Sanitation and Hygiene for Development, 5, pp.115-126.

Majorin, F, Freeman, MC, Barnard, S, Routray, P, Boisson, S and Clasen, T 2014. Child feces disposal practices in rural Orissa: A cross sectional study. PLOS One, 9, e89551.

O'Reilly, K, Louis, E, Thomas, E and Sinha, A, 2015. Combining sensor monitoring and ethnography to evaluate household latrine usage in rural India. Journal of Water Sanitation and Hygiene for Development, 5, pp.426-438.

Patil, SR, Arnold, BF, Salvatore, AL, Briceno, B, Sandipan, G, Colford, JM, Jr and Gertler, PJ, 2014. The effect of India's total sanitation campaign on defecation behaviors and child health in rural Madhya Pradesh: a cluster randomized controlled trial. PLOS Medicine, p.11.

Pattanayak, SK, Yang, JC, Dickinson, KL, Poulos, C, Patil, SR, Mallick, RK, Blitstein, JL and Purujit, P, 2009. Shame or subsidy revisited: social mobilization for sanitation in Orissa, India (Special Theme: Public Health Communication). Bulletin of the World Health Organization, 87, pp.580-587.

Zacharia, S and Shordt, K, 2004. How to change and sustain hygiene behaviours: Research in India. People-Centred Approaches to Water and Environmental Sanitation: Proceedings of the 30th WEDC Conference, pp.164-169. 


\section{References}

Banda, K, Sarkar, R, Gopal, S, Govindarajan, J, Harijan, BB, Jeyakumar, MB, Mitta, P, Sadanala, ME, Selwyn, T, Suresh, CR, Thomas, VA, Devadason, P, Kumar, R, Selvapandian, D, Kang, G and Balraj, V, 2007. Water handling, sanitation and defecation practices in rural southern India: A knowledge, attitudes and practices study. Transactions of the Royal Society of Tropical Medicine and Hygiene, 101, 1124-1130.

Barnard, S, Routray, P, Majorin, F, Peletz, R, Boisson, S, Sinha, A and Clasen, T, 2013. Impact of Indian total sanitation campaign on latrine coverage and use: A cross-sectional study in Orissa three years following programme implementation. PLOS ONE, 8(8).

Chambers, R, 2009. Going to scale with community-led total sanitation: Reflections on experience, issues and ways forward. IDS Practice Papers, 2009, 1-50.

Clasen, T, Boisson, S, Routray, P, Torondel, B, Bell, M, Cumming, O, Ensink, J, Freeman, M, Jenkins, M, Odagiri, M, Ray, S, Sinha, A, Suar, M and Schmidt, WP, 2014. Effectiveness of a rural sanitation programme on diarrhoea, soil-transmitted helminth infection, and child malnutrition in Odisha, India: a cluster-randomised trial. The Lancet Global Health, 2, e645-e653.

Coalition for Evidence-Based Policy, 2010. Checklist for reviewing a randomized controlled trial of a social program or project, to assess whether it produced valid evidence.

Coffey, D, Gupta, A, Hathi, P, Khurana, N, Spears, D, Srivastav, N and Vyas, S, 2014. Revealed preference for open defecation. Economic and Political Weekly, 49, 43.

De Buck, E, Van Remoortel, H, Hannes, K, Govender, T, Naidoo, S, Avau, B, Musekiwa, A, Lutje, V, Cargo, M and Mosler, H-J, 2017. Approaches to promote handwashing and sanitation behaviour change in low-and middle income countries: A mixed method systematic review. Campbell Systematic Reviews, 7, 1-447.

Devine, J, 2009. Introducing SaniFOAM: A framework to analyze sanitation behaviors to design effective sanitation programs. Water and sanitation program working paper. Washington, DC: World Bank.

Dickinson, KL, 2008. Indian toilets and Tanzanian mosquito nets: Understanding households' environmental health decisions in developing countries. Dissertation Abstracts International Section A: Humanities and Social Sciences, 69, 1078.

Dreibelbis, R, Jenkins, M, Chase, RP, Torondel, B, Routray, P, Boisson, S, Clasen, T and Freeman, MC, 2015. Development of a multidimensional scale to assess attitudinal determinants of sanitation uptake and use. Environmental Science \& Technology, 49, 13613-13621.

Dreibelbis, R, Winch, PJ, Leontsini, E, Hulland, KR, Ram, PK, Unicomb, L and Luby, SP, 2013. The integrated behavioural model for water, sanitation, and hygiene: A systematic review of behavioural models and a framework for designing and evaluating behaviour change interventions in infrastructure-restricted settings. BMC Public Health, 13, 1-13. 
Fishbein, M and Ajzen, I, 1975. Belief, attitude, intention, and behavior: An introduction to theory and research. Reading, MA: Addison-Wesley.

Government of India, 2011. Assessment study of impact and sustainability of Nirmal Gram Puraskar. Department of Drinking Water and Sanitation, Ministry of Rural Development, Government of India.

Government of India, 2012. Total sanitation campaign sanitation for all - 2012. In Sanitation, MODWA (ed.). New Delhi, India: Ministry of Drinking Water and Sanitation.

Gupta, A, Coffey, D and Spears, D, 2016. Purity, pollution, and untouchability: Challenges affecting the adoption, use, and sustainability of sanitation programmes in rural India. Sustainable Sanitation for All: Experiences, challenges, and innovations, 283.

Hirve, S, Lele, P, Sundaram, N, Chavan, U, Weiss, M, Steinmann, P and Juvekar, S, 2015. Psychosocial stress associated with sanitation practices: Experiences of women in a rural community in India. Journal of Water Sanitation and Hygiene for Development, 5, 115-126.

Hulland, K, Martin, N, Dreibelbis, R, Debruiker VJ and Winch, P, 2015a. What factors affect sustained adoption of safe water, hygiene and sanitation technologies? A systematic review of the literature. EPPI-Centre, Social Science Research Unit, UCL Institute of Education, University College London.

Hulland, KRS, Chase, RP, Caruso, BA, Swain, R, Biswal, B, Sahoo, KC, Panigrahi, P and Dreibelbis, R, 2015b. Sanitation, stress, and life stage: A systematic data collection study among women in Odisha, India. PLOS ONE, 10, e0141883.

Human Rights Watch, 2014. Cleaning human waste: 'Manual scavenging', caste and discrimination in India.Available at:

<https://www.hrw.org/sites/default/files/reports/india0814_ForUpload.pdf>.

Ioannidis, J, Patsopoulos, N and Rothstein, H, 2008. Research methodology: Reasons or excuses for avoiding meta-analysis in forest plots. British Medical Journal, 336, 14131415.

Jenkins, M, Freeman, M and Routray, P, 2014. Measuring the safety of excreta disposal behavior in india with the new safe san index: Reliability, validity and utility. International Journal of Environmental Research and Public Health, 11, 8319.

Kar, K and Chambers, R, 2008. Handbook on Community-Led Total Sanitation. London, UK, Plan UK; Brighton, UK: Institute of Development Studies at the University of Sussex.

Kar, K, 2003. Subsidy or self-respect? Participatory total community sanitation in Bangladesh. Working paper series. Brighton: Institute of Development Studies.

Majorin, F, Freeman, MC, Barnard, S, Routray, P, Boisson, S and Clasen, T, 2014. Child feces disposal practices in rural Orissa: A cross sectional study. PLOS One, 9, e89551.

Mara, D, Lane, J, Scott, B and Trouba, D, 2010. Sanitation and health. PLOS Med, 7, e1000363. 
Marteau, TM, Hollands, GJ and Fletcher, PC, 2012. Changing human behavior to prevent disease: The importance of targeting automatic processes. Science, 337, 14921495.

Mosler, $\mathrm{HJ}, 2012$. A systematic approach to behavior change interventions for the water and sanitation sector in developing countries: A conceptual model, a review, and a guideline. International Journal of Environmental Health Research, 22.

Neal, D and Vujcic, J, 2016. Nudging and habit change for open defecation: new tactics from behavioral science.

O'Reilly, K, Louis, E, Thomas, E and Sinha, A, 2015. Combining sensor monitoring and ethnography to evaluate household latrine usage in rural India. Journal of Water Sanitation and Hygiene for Development, 5, 426-438.

Patil, SR, Arnold, BF, Salvatore, AL, Briceno, B, Sandipan, G, Colford, JM, Jr. and Gertler, PJ, 2014. The effect of India's total sanitation campaign on defecation behaviors and child health in rural Madhya Pradesh: a cluster randomized controlled trial. PLOS Medicine, 11.

Pattanayak, SK, Yang, JC, Dickinson, KL, Poulos, C, Patil, SR, Mallick, RK, Blitstein, JL and Purujit, P, 2009. Shame or subsidy revisited: social mobilization for sanitation in Orissa, India (Special theme: Public health communication). Bulletin of the World Health Organization, 87, 580-587.

Routray, P, Schmidt, W-P, Boisson, S, Clasen, T and Jenkins, MW, 2015a. Sociocultural and behavioural factors constraining latrine adoption in rural coastal Odisha: an exploratory qualitative study. BMC Public Health, 15, 1-19.

Sahoo, KC, Hulland, KR, Caruso, BA, Swain, R, Freeman, MC, Panigrahi, P and Dreibelbis, R, 2015. Sanitation-related psychosocial stress: A grounded theory study of women across the life-course in Odisha, India. Social Science \& Medicine, 139, 80-89.

Shah, A, Thathachari, J, Agarwai, R and Karamchandani, A, 2013. White paper: A market led, evidence based approach to rural sanitation.

Sigler, R, Mahmoudi, L and Graham, JP, 2015. Analysis of behavioral change techniques in community-led total sanitation programs. Health Promotion International, 30, 16-28.

Sinha, A, Nagel, CL, Thomas, E, Schmidt, WP, Torondel, B, Boisson, S and Clasen, TF, 2016. Assessing latrine use in rural India: A cross-sectional study comparing reported use and passive latrine use monitors. The American Journal of Tropical Medicine and Hygiene, 16-0102.

Spears, D and Lamba, S, 2015. Effects of early-life exposure to sanitation on childhood cognitive skills: evidence from India's total sanitation campaign. Journal of Human Resources. 
United Nations Children's Fund (UNICEF) India, 2016. Eliminate open defecation [Online]. UNICEF. Accessed 11 March 2016. Available at:

<http://unicef.in/Whatwedo/11/Eliminate-Open-Defecation 2016>.

Waddington, H, Snilstveit, B, Hombrados, JG, Vojtkova, M, Anderson, J and White, H, 2014. Farmer field schools for improving farming practices and farmer outcomes in lowand middle-income countries: a systematic review. Campbell systematic reviews, 10.

Waterkeyn, J and Cairncross, S, 2005. Creating demand for sanitation and hygiene through community health clubs: A cost-effective intervention in two districts in Zimbabwe. Social Science \& Medicine, 61.

Routray, P, Schmidt, W-P, Boisson, S, Clasen, T and Jenkins, MW 2015. Socio-cultural and behavioural factors constraining latrine adoption in rural coastal Odisha: An exploratory qualitative study. BMC public health, 15, 880.

World Bank 2011. Economic impacts of inadequate sanitation in india. In: Water and Sanitation Program, WB (ed.). Washington, DC: World Bank.

World Bank, 2013. Pathway to success: compendium of best practices in rural sanitation in India. Water and Sanitation Program. Washington, DC: World Bank Group. Available at: http://documents.worldbank.org/curated/en/503661468041400782/Pathway-tosuccess-compendium-of-best-practices-in-rural-sanitation-in-India>.

World Bank, 2014. Overview: Human decision making and development policy. World development report 2015: Mind, Society, and Behavior.

World Health Organization and United Nations Children's Fund (WHO/UNICEF), 2015. Joint monitoring programme for water supply and sanitation. In: WHO/UNICEF (ed.) Progress on Sanitation and Drinking Water: 2015 Update. Geneva.

Zacharia, S and Shordt, K, 2004. How to change and sustain hygiene behaviours: Research in India. People-Centred Approaches to Water and Environmental Sanitation: Proceedings of the 30th WEDC Conference, pp.164-169. 


\section{Other publications in the 3ie Scoping Paper Series}

The following papers are available from http://www.3ieimpact.org/en/publications/3iescoping-paper-series/

Integrating HIV services with other health services to improve care, retention and adherence, 3ie Scoping Report 7. Heard, AC, Peterson, K, Modi, S, Esper, H, Calvo, F and Brown, AN (2017)

Assessing the evidence base on science, technology, innovation and partnerships for accelerating development outcomes in low- and middle-income countries. 3ie Scoping Paper 6. Sabet, SM, Heard, AC, Neilitz, S and Brown, AN (2017)

Adolescent sexual and reproductive health: the state of evidence on the impact of programming in low- and middle-income countries. 3ie Scoping Paper 5. Rankin, $\mathrm{K}$, Heard, AC and Diaz, N (2016)

The state of evidence on the impact of transferable skills programming on youth in lowand middle-income countries, 3ie Scoping Paper 4. Brown AN, Rankin, K, Picon, M and Cameron, DB (2015)

Engaging communities for increasing immunisation coverage: What do we know?. 3ie Scoping Paper 3. Sabarwal, S, Bhatia, R, Dhody, B, Perumal, S, White, H and Puri, J (2015)

The current state of peacebuilding programming and evidence. 3ie Scoping paper 2. Brown, AN, McCollister, F, Cameron, DB and Ludwig, J (2015)

What evidence is available and what is required, in humanitarian assistance?, 3ie Scoping Paper 1. Clarke, M, Allen, C, Archer, F, Wong, D, Eriksson, A and Puri, J (2014) 
To inform 3ie's Promoting Latrine Use in Rural India Thematic Window, this scoping study examines the state of rigorous evidence with this focus. The authors highlight findings from a systematic search of quantitative literature, expert consultations and a rural field visit. They also examine how latrine use is measured, and the inherent biases in commonly used approaches. Our results demonstrate a lack of rigorous evidence on rural Indian latrine use. The authors find that a number of beliefs, attitudes and practices inhibit the uptake of safe sanitation. Poor quality of the latrine and the perceived convenience of open defecation also appear to be major barriers to the adoption of safe sanitation practices.

\section{Scoping Paper Series}

International Initiative for Impact Evaluation

202-203, 2nd Floor, Rectangle One

D-4, Saket District Center

New Delhi - 110017

India

3ie@3ieimpact.org

Tel: +91 1149894444 